\title{
Techno-economic evaluation of multiple energy piles for a ground-coupled
}

\section{heat pump system}

Yuanlong Cui a, b, Jie Zhu ${ }^{\text {a* }}$, Fanran Meng ${ }^{\mathrm{c}}$

${ }^{\text {a }}$ Department of Architecture and Built Environment, University of Nottingham, Nottingham, NG7 2RD, United Kingdom

${ }^{\mathrm{b}}$ UK Greenergy Pathways Ltd., Queens Road, Nottingham, NG9 2JW, United Kingdom

${ }^{\mathrm{c}}$ Department of Mechanical, Materials and Manufacturing Engineering, University of Nottingham, Nottingham, NG7 2RD, United Kingdom

\begin{abstract}
A technical and economic feasibility study of multiple energy piles (EPs) for a ground-coupled heat pump (GCHP) system is presented in this paper. The GCHP system energy performance and life-cycle cost (LCC) are evaluated, it is found that the system energy output (heating and cooling) could meet a domestic building comfortable environment requirement with the annual average COP of 3.63 and EER of 4.62. The LCC evaluation indicates that the system net present value (NPV) is approximately $£ 26,095$ at the market discount rate of $8.75 \%$ for a 20 -year operating period. Moreover, the payback period of the GCHP system is approximately 4.31 years, which is sensitive to the main parameters including electricity price, capital investment and energy generation. Furthermore, the low discount rate and high energy generation are beneficial to the GCHP system with the high NPV and cash flows. The capital price of the system should be regulated to a lower level for the larger market potential.
\end{abstract}

Keywords: Ground-coupled heat pump, Energy pile, System performance, Life-cycle cost, Net present value, Payback period

\section{Introduction}

In recent years the dramatic concerns about climate change by using fossil fuels, and their accompanying costs, have driven governments, companies and consumers towards renewable energy resources, the European Parliament directive 2010/31/EU [1] on building energy performance has been adopted to accelerate renewable energy application in building sector. Currently, there are more than 160 million buildings over the whole of Europe which consume approximately $40 \%$ of the primary energy for

\footnotetext{
${ }^{*}$ Corresponding author. Tel: +44-115-8466141 Fax: +44-115-951315

E-mail address: jie.zhu@nottingham.ac.uk
} 
heating, cooling and electricity [2, 3]. Decreasing the building sector primary energy consumption will make a substantial contribution towards achieving the EU's 2020, the UK's 2050 and other international $\mathrm{CO}_{2}$ emission targets. Therefore, renewable energy technologies become more prevalent and are widely used in energy-efficient and cost-effective buildings.

1.1 Energy pile (EP) technology

One of the prevalent renewable energy sources is shallow geothermal energy, which can be used to fulfil building heating and cooling needs by ground-coupled heat pump (GCHP) system. A typical GCHP system includes three essential components: (i) a heat pump, (ii) a ground heat exchanger (GHE), and (iii) a piping network. In heating season, soil is regarded as a heat source for the GCHP system while in cooling season, it is treated as a heat sink. In terms of most regions of Europe, the seasonal soil temperature is relatively stabilized with ranging from $10^{\circ} \mathrm{C}$ to $15^{\circ} \mathrm{C}$ underneath a depth of $10-15 \mathrm{~m}$, symbolizing good condition for heat extracted and rejected [4]. Due to the requirement of large land area for the horizontal loop and high expense for the vertical loop, the GHE pipes can be mounted inside building structural foundation elements referred as energy pile (EP) [5, 6] as presented in Fig.1.

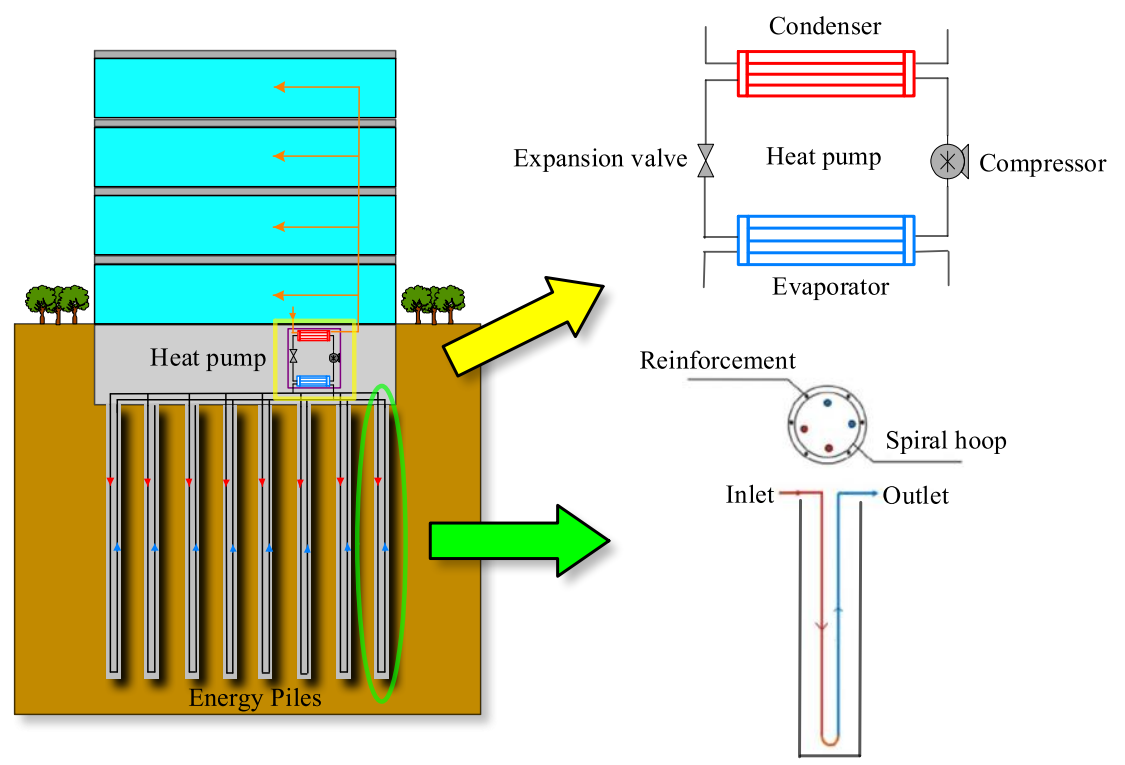

Fig.1. The schematic diagram of EPs foundation

The EP primary advantage is its dual functions as heat exchanger and building structural element. Meanwhile, concrete is utilized as an ideal heat transfer medium for heat transfer because of its high thermal energy storage capacity and thermal conductivity $[7,8]$. It is found that the GCHP system with EPs can achieve energy-saving of approximately $75 \%$ in comparison to the traditional air conditioning system [9-13]. In the past decades, there are several EP systems mounted in Europe, particularly in United Kingdom, Germany, Switzerland and Austria [14]. Some case studies have been carried out including Zurich airport in Germany [15], international solar centre in Berlin [16], multi-purpose hall in Austria [17] and Keble College in Oxford [18]. In excess of three hundred foundation EPs have been installed at Dock Midfield Zurich airport [15], and the system performance 
evaluation reveals that about $85 \%$ of the annual heating requirement and $100 \%$ of the annual cooling need are covered by the system. International solar centre in Berlin adopted 200 EPs to cover $20 \%$ of heating and 100\% of cooling requirements [16]. 320 EPs with $18 \mathrm{~m}$ length were installed in a multi-purpose hall with a capacity of 8,000 people in Austria for space heating and cooling, the installed system could save natural gas of $85,000 \mathrm{~m}^{3}$ per annum, which is equivalent to a reduction of $\mathrm{CO}_{2}$ emission of 73 tons [17]. One of the largest projects is at the Keble College Oxford, which is also the first EP structure in the UK, established in 2001 [18]. Since then, the number of mounted EPs in the UK has promptly increased, with almost 4,600 EPs (cumulative) until 2010 [19].

Recently, the performance improvement of the GCHP system with EPs has received more attentions, owing to the fact that it is one of the most effective measures for building air conditioning [20], therefore, some research works [21-24] have been implemented to study its heat transfer features. Hamada et al. [21] analysed the performance of an EP unit, and found that the unit makes up about $90 \%$ of building thermal energy requirement as well as the average heating COP is 3.9. Darkwa et al. [22] investigated a single EP performance during the long-term operating period, and concluded that the annual average thermal energy rejected into ground is about 4.5 times higher than the amount extracted. Kim et al. [23] utilized the TRNSYS software to evaluate the system performance of a GCHP with EPs, and obtained that the COP values can be increased by $25.2 \%$ and $15.1 \%$ under heating and cooling modes, respectively. Capozza et al. [24] compared the performance characteristics between a hybrid GCHP with a heat storage bath and a pure one, and discovered that the average COP of the hybrid system is approximately $7.2 \%$ higher than that of the pure one at the optimum running circumstance.

\subsection{Economic evaluation}

Due to their merits of the GCHP system with EPs, some studies [25-33] focus on the techno-economic assessment for various EPs categories in different regions. Most of them assess the system energy performance by various approaches, and then analyse and predict financial benefits based on different economic indicators, such as life cycle cost (LCC) [27-34], Monte Carlo method [32], Bin method [33], life cycle assessment (LCA) [35-37], discounted cash flow analysis (DCFA) [38], discounted payback period (DPB) [28], and simple payback period (SPB) [27,30]. According to these research results, it can be found for the GCHP system with EPs that: 1) its net present value (NPV) is approximately $£ 24,000-£ 30,000$ for a 20 -25 years’ service lifetime; 2 ) its payback period is about $4-10$ years in general.

Bristow et al. [25] demonstrated the GCHP technology in Canada, and their results indicate that the technology can not only reduce $\mathrm{CO}_{2}$ emission but also shorten the payback time. Yoon and Lee [26] studied the LCC of a GCHP at Korean Incheon International airport by one intelligent operating method to decrease the energy consumption and operating bills. Chiasson [27] analysed three air conditioning systems for an office building in Nebraska, USA, and obtained that the GCHP unit has the lowest LCC over air-source heat pump (ASHP), direct expansion (DX) cooling and gas heating units, as well as its payback period is 
approximately 6.5 years. Morrone et al. [28] compared the cost effectiveness between the conventional and EPs systems by using NPV and discounted payback time (DPB) methods in Naples and Milan of Italy. It is demonstrated that the cost-saving of EPs system can be achieved approximately $20 \%$ with $8-11$ years' DPB in comparison to the conventional unit in Naples, while the saving is predicted no more than $10 \%$ with 4 years' DPB in Milan. Vu et al. [29] proposed an economic model to optimize the LCC of a GCHP system in view of the impact of pipe size and heat pump capacity on different U-type heat exchangers. Their results reflect that the pipe size and heat pump capacity have more effects on the coil-type GHEs than that of other U-type GHEs. Ren et al. [30] estimated energy and economic benefits of the GCHP units with both steel and polyethylene (PE) heat exchangers in China, and discovered that the investment of the steel heat exchanger and energy consumption are less than the PE one by $35.2 \%$ and $45.6 \%$, respectively. The payback periods of the steal and PE heat exchangers reach 1.83 years and 3.45 years, respectively. Canbek [31] reported that the GCHP systems could save about 45-55\% of heating and cooling expenses for residential buildings in the hot and humid climate. Zhu et al. [32] studied the LCC of a GCHP system based on the Monte Carlo method for a commercial building in USA and compared with the probabilistic method by @ risk software with considering the data uncertainties. They confirmed that the GCHP unit is more favourable than the conventional system. Lu et al. [33] assessed the performances of several GCHP units and compared their costs against other traditional heating and cooling system's based on the Bin method in Melbourne, and revealed that for a design lifetime of 20 years, the ASHP is more economically attractive than the GCHP unit whereas for a design life of 40 years, the GCHP system can produce more saving than other alternatives. Arat and Arslan [34] implemented economic analysis for a GCHP system to provide district heating for a town centre with a population of about 25,000 in Turkey through the LCC method, and denoted that the system can supply enough heat for the residences in a figure between 7,929 and 46,098 along with NPV varying from US\$ 1,192.81 to US\$23.20 million.

Based on the aforementioned techno-economic assessments for the GCHP system with EPs, many studies have been implemented on energy performance and LCC analysis, the long-term performance assessment is one of the challenges to integrate the system into domestic building. Furthermore, the main obstacles in using LCC involve life of assets, erratic economic alteration, uncertainty factors concerning interest and discount rates, as well as future maintenance expense, NPV and payback period. The purpose of this paper is to assess the techno-economic characteristics of a GCHP system with EPs for a long-term operating period. The system seasonal operating performance, soil heat extracted/rejected rates, annual energy generation (heating and cooling) from the GCHP system are all determined by using the Engineering Equation Solver (EES) software. Furthermore, the system LCC assessment is carried out through the @ Risk software considering the time value of the money to investigate the NPV and cumulative energy cost savings for 20 years of service lifetime. The key factors are taken into account in the complete LCC analysis, these include inflation rate, income tax rate, discount rate, interest rate, capital investment (CI), loan payment (LP), system energy cost (SEC), maintenance cost (MC), periodic cost (PC), present value (PV) of money and 
cumulative EP system savings (EPS). Meanwhile, the payback period is also obtained according to the values of cash flows and cumulative system energy cost (SEC) savings.

\section{2. System description}

112 The building selected in this study is a two-storey family house in Birmingham, UK [39, 40]. The operation period of the GCHP system with multiple EPs is from October/2007 to September/2008. Data regarding the building geometry and system parameters are obtained from the project plan and specifications $[39,40]$. The diagram of EPs array layout is given in Fig.2.

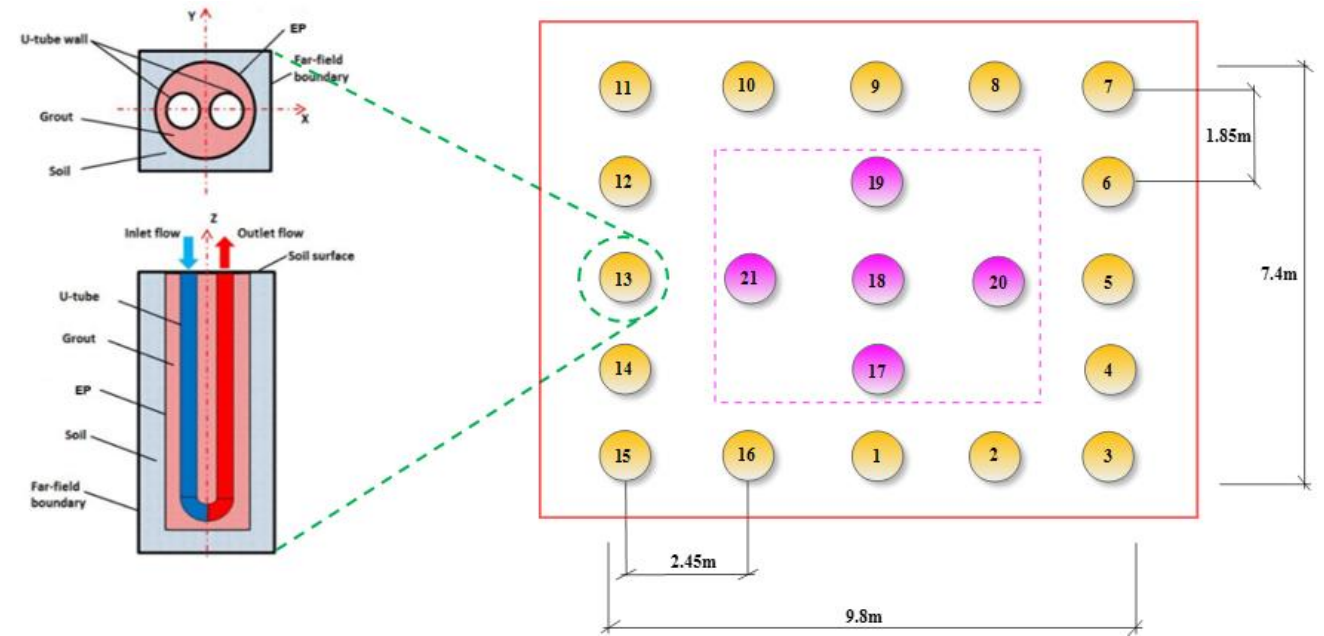

Fig.2. The diagram of multiple EPs array layout

The total number of EPs established is 21, which would be essential for the foundation demand of the family house. Nevertheless, only the perimeter 16 EPs are employed to exchange heat with ground. Each EP has a diameter of $0.3 \mathrm{~m}$ with $10 \mathrm{~m}$ depth. The U-tube is constructed with an external diameter of $0.032 \mathrm{~m}$ and wall thickness of $0.0029 \mathrm{~m}$. The major parameters of EP are illustrated in Table 1.

121 Table 1 Geometrical parameters and initial conditions [39, 40]

\begin{tabular}{ll}
\hline Description & Value \\
\hline Pipe external diameter & $0.032 \mathrm{~m}$ \\
Pipe internal diameter & $0.0262 \mathrm{~m}$ \\
EP diameter & $0.3 \mathrm{~m}$ \\
Shank spacing & $0.06 \mathrm{~m}$ \\
EP depth & $10 \mathrm{~m}$ \\
Initial ground surface temperature & $10.4{ }^{\circ} \mathrm{C}$ \\
Soil temperature & $15.0{ }^{\circ} \mathrm{C}$ \\
Soil bottom temperature & $15.5{ }^{\circ} \mathrm{C}$ \\
Fluid inlet temperature & $1.2{ }^{\circ} \mathrm{C}$ \\
\hline
\end{tabular}

\subsection{Building energy demands}

124 The domestic building with the whole floor area of $144 \mathrm{~m}^{2}$ is designed for one family of four people, and its mean monthly ambient temperatures and energy (heating and cooling) demands are given in Fig.3 [39]. The lowest and highest temperatures 
reach $4.75{ }^{\circ} \mathrm{C}$ in December and $17.38{ }^{\circ} \mathrm{C}$ in August, respectively. The maximum and minimum heating energy demands are 3,154.85 $\mathrm{kWh}$ and $1,372.96 \mathrm{kWh}$, respectively. On the other hand, the maximum and minimum cooling energy are $1,488.12$

$128 \mathrm{kWh}$ and $862.49 \mathrm{kWh}$, respectively.

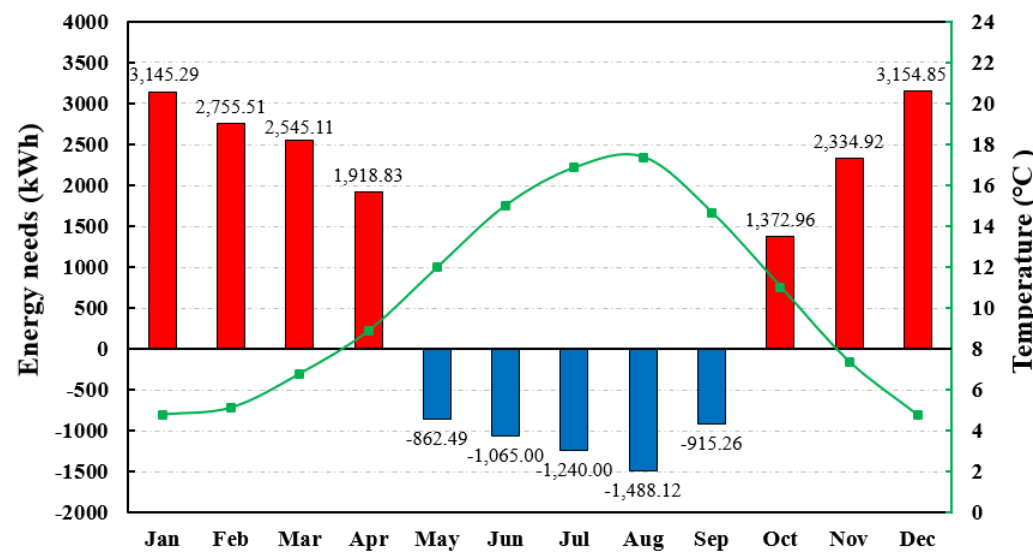

Fig.3. Monthly energy demands and ambient temperatures

1312.2 Heat pump system

The EPs are linked to a $5.9 \mathrm{~kW}$ Greenline HT Plus heat pump $[39,40]$ which generates hot water at a temperature range between

$35^{\circ} \mathrm{C}$ and $65^{\circ} \mathrm{C}$. Technical specifications of the Greenline HT Plus [41] are given in Table 2. The main thermal property parameters are shown in Table 3.

135 Table 2 Nominal specifications of the heat pump [39, 41]

\begin{tabular}{ll}
\hline Description & Value \\
\hline Emitted $/$ Supplied output at $0 / 35^{\circ} \mathrm{C}$ & $5.9 / 1.3 \mathrm{~kW}$ \\
Refrigerant R407C mass flow rate & $0.02 \mathrm{~kg} / \mathrm{s}$ \\
Superheat & $3{ }^{\circ} \mathrm{C}$ \\
Subcooling & $4{ }^{\circ} \mathrm{C}$ \\
Nominal flow heating medium & $0.201 / \mathrm{s}$ \\
Minimum flow heating medium & $0.141 / \mathrm{s}$ \\
\hline
\end{tabular}

Table 3 Thermal property parameters

Fluid (mixture of glycol and water)

\begin{tabular}{ll}
\hline Density & $1,035 \mathrm{~kg} / \mathrm{m}^{3}$ \\
Kinematic viscosity & $4.94 \times 10^{-6} \mathrm{~m}^{2} / \mathrm{s}$ \\
Heat capacity & $3,795 \mathrm{~J} /(\mathrm{kg} \cdot \mathrm{K})$ \\
Thermal conductivity & $0.58 \mathrm{~W} /(\mathrm{m} \cdot \mathrm{K})$ \\
\hline
\end{tabular}

\section{Pipe(High density polyethylene)}

\begin{tabular}{lll}
\hline Pipe(High density polyethylene) & \\
\hline Density & $950 \mathrm{~kg} / \mathrm{m}^{3}$ \\
Heat capacity & $2,300 \mathrm{~J} /(\mathrm{kg} \cdot \mathrm{K})$ \\
Thermal conductivity & $0.45 \mathrm{~W} /(\mathrm{m} \cdot \mathrm{K})$ & \\
\hline Filling (Grout) & $1,860 \mathrm{~kg} / \mathrm{m}^{3}$ \\
\hline Density & $840 \mathrm{~J} /(\mathrm{kg} \cdot \mathrm{K})$ & \\
Heat capacity & $2 \mathrm{~W} /(\mathrm{m} \cdot \mathrm{K})$ & Density \\
Thermal conductivity & Thermal conductivity & $2,277 \mathrm{~kg} / \mathrm{m}^{3}$
\end{tabular}




\begin{tabular}{llll} 
& Sand gravel $2.22 \mathrm{~m}$ to $3.3 \mathrm{~m}$ & $1.15 \mathrm{~W} /(\mathrm{m} \cdot \mathrm{K})$ & $2,094 \mathrm{~kg} / \mathrm{m}^{3}$ \\
Soil & Gravelly Clay $3.3 \mathrm{~m}$ to $5.5 \mathrm{~m}$ & $1.68 \mathrm{~W} /(\mathrm{m} \cdot \mathrm{K})$ & $2,223 \mathrm{~kg} / \mathrm{m}^{3}$ \\
& Gravelly Clay $5.5 \mathrm{~m}$ to $10 \mathrm{~m}$ & $1.75 \mathrm{~W} /(\mathrm{m} \cdot \mathrm{K})$ & $2,392 \mathrm{~kg} / \mathrm{m}^{3}$ \\
& Weighted mean & $1.50 \mathrm{~W} /(\mathrm{m} \cdot \mathrm{K})$ & $2,260 \mathrm{~kg} / \mathrm{m}^{3}$ \\
\hline
\end{tabular}

\section{3. Methodology}

$140 \quad 3.1$ Energy analysis model

$141 \quad$ 3.1.1 EP thermal energy output

142 The energy output of the multiple EPs unit is determined based on the local weather data and a 2D thermal resistance model as shown in Fig.4.
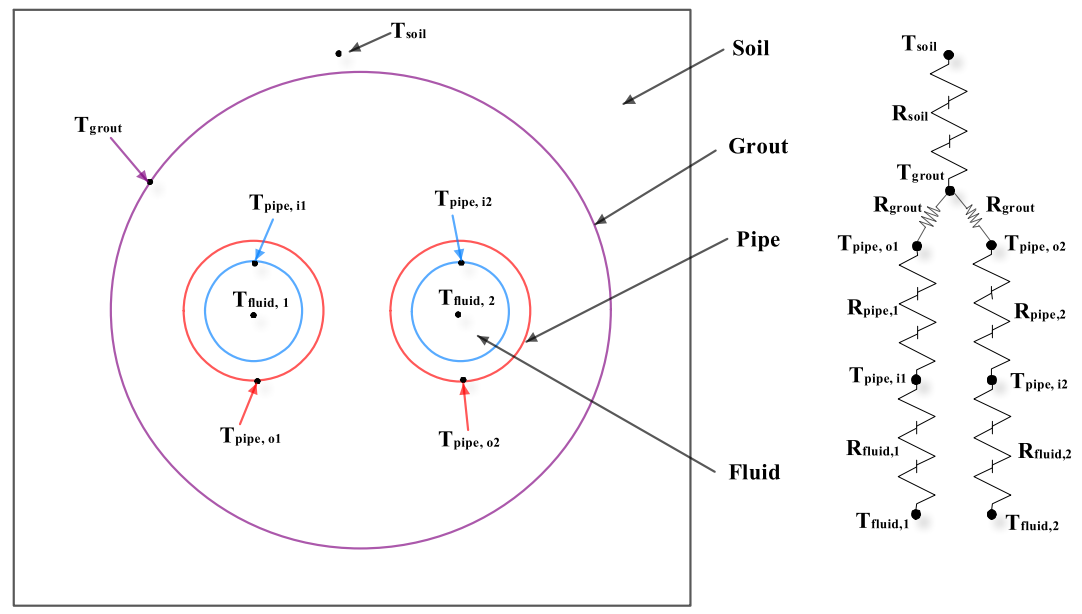

Fig.4. Cross-section of EP and corresponding thermal resistance circuit

Under the steady operating condition, the heat extracted/rejected rate from the soil $\left(\mathrm{Q}_{\text {soil }}\right)$ is given by [42]:

$147 \mathrm{Q}_{\text {soil }}=\mathrm{U} \cdot \mathrm{A}_{\text {pipe }} \cdot \Delta \mathrm{T}_{\mathrm{LMTD}}$

where $\mathrm{U}$ is the total heat transfer coefficient $\left(\mathrm{W} / \mathrm{m}^{2} \cdot \mathrm{K}\right) ; \mathrm{A}_{\text {pipe }}$ is the surface area of the U-tube pipe $\left(\mathrm{m}^{2}\right) ; \Delta \mathrm{T}_{\mathrm{LMTD}}$ is the logarithmic

149 mean temperature difference. $\Delta \mathrm{T}_{\mathrm{LMTD}}$ is obtained by $[42]$ :

150

$$
\Delta \mathrm{T}_{\text {LMTD }}=\frac{\left|\mathrm{T}_{\text {outlet }}-\mathrm{T}_{\text {inlet }}\right|}{\ln \left|\frac{\left(\mathrm{T}_{\text {outlet }}-\mathrm{T}_{\text {soil }}\right)}{\left(\mathrm{T}_{\text {inlet }}-\mathrm{T}_{\text {soil }}\right)}\right|}
$$

151 where $\mathrm{T}_{\text {inlet }}$ and $\mathrm{T}_{\text {outlet }}$ are the inlet and outlet working fluid temperatures $\left({ }^{\circ} \mathrm{C}\right)$, respectively; $\mathrm{T}_{\text {soil }}$ is the soil temperature $\left({ }^{\circ} \mathrm{C}\right)$.

152 The total heat transfer coefficient can be calculated by thermal resistance equations [42]:

$153 \quad \mathrm{U}=\frac{1}{\mathrm{R}_{\text {total }}}$

154

$\mathrm{R}_{\text {total }}=\mathrm{R}_{\text {fluid }}+\mathrm{R}_{\text {pipe }}+\mathrm{R}_{\text {grout }}+\mathrm{R}_{\text {soil }}$ 
155 where $\mathrm{R}_{\text {fluid }}$ is the working fluid thermal resistance $(\mathrm{K} / \mathrm{W}) ; \mathrm{R}_{\text {pipe }}$ is the pipe thermal resistance $(\mathrm{K} / \mathrm{W})$; $\mathrm{R}_{\text {grout }}$ is the grout thermal 156 resistance $(\mathrm{K} / \mathrm{W})$; $\mathrm{R}_{\text {soil }}$ is the soil thermal resistance $(\mathrm{K} / \mathrm{W})$.

$157 \quad \mathrm{R}_{\text {fluid }}=\frac{1}{2 \pi \mathrm{r}_{\text {inner }} \mathrm{Lh}_{\text {fluid }}}$

158 where $r_{\text {inner }}$ is the internal radius of pipe $(\mathrm{m}) ; \mathrm{L}$ is the EP length $(\mathrm{m}) ; \mathrm{h}_{\text {fluid }}$ is the convective heat transfer coefficients of the 159 working fluid within pipe $(\mathrm{W} / \mathrm{m} \cdot \mathrm{K})$.

160 Based on the Gnielinski correlation, the convective heat transfer coefficient is given as:

$161 \quad \mathrm{~h}_{\text {fluid }}=\frac{\mathrm{Nu}_{\mathrm{D}_{\mathrm{H}}} \cdot \lambda_{\text {fluid }}}{2 \mathrm{r}_{\text {inner }}}$

162 where $\lambda_{\text {fluid }}$ is the thermal conductivity of the working fluid $\left(\mathrm{W} / \mathrm{m}^{2} \cdot \mathrm{K}\right)$.

163 The Nusselt number is given as [43]:

$164 \quad \mathrm{Nu}_{\mathrm{D}_{\mathrm{H}}}=\frac{(\mathrm{f} / 8) \times\left(\mathrm{Re}_{\mathrm{D}_{\mathrm{h}}}-1000\right) \times \operatorname{Pr}}{1+12.7 \times \sqrt{(\mathrm{f} / 8)} \times\left(\operatorname{Pr}^{2 / 3}-1\right)}$

165 where $\mathrm{f}$ is the Dracy friction factor; Re and Pr are the working fluid Reynolds and Prandtl numbers, respectively.

166 The Dracy friction factor is given by [43]:

$167 \mathrm{f}=\left[0.790 \times \ln \left(\operatorname{Re}_{\mathrm{D}_{\mathrm{h}}}\right)-1.64\right]^{-2}$

168 Re and Pr are written as:

$169 \quad \operatorname{Re}_{D_{H}}=\frac{\rho_{\text {fluid }} v_{\text {fluid }} D_{H}}{\mu_{\text {fluid }}}$

$170 \operatorname{Pr}=\frac{\mathrm{c}_{\text {fluid }} \mu_{\text {fluid }}}{\lambda_{\text {fluid }}}$

171 where $\rho_{\text {fluid }}$ is the working fluid density $\left(\mathrm{kg} / \mathrm{m}^{3}\right) ; v_{\text {fluid }}$ is the working fluid velocity $\left(\mathrm{m}^{2} / \mathrm{s}\right)$; $\mu_{\text {fluid }}$ is the working fluid dynamic 172 viscosity $(\mathrm{Pa} \cdot \mathrm{s}) ; \mathrm{D}_{\mathrm{H}}$ is the hydraulic dimeter $(\mathrm{m})$.

$173 \quad \mathrm{R}_{\text {pipe }}=\frac{1}{2 \pi \mathrm{L} \lambda_{\text {pipe }}} \ln \frac{\mathrm{r}_{\text {outer }}}{\mathrm{r}_{\text {inner }}}$

174 where $\lambda_{\text {pipe }}$ is the thermal conductivity of the pipe material $\left(\mathrm{W} / \mathrm{m}^{2} \cdot \mathrm{K}\right) ; \mathrm{r}_{\text {outer }}$ is the pipe outer radius $(\mathrm{m})$.

$175 \mathrm{R}_{\text {grout }}$ is given by $[44,45]$

176

$\mathrm{R}_{\text {grout }}=\frac{1}{2 \pi \mathrm{L} \lambda_{\text {grout }}} \ln \frac{\mathrm{r}_{\mathrm{EP}}}{\mathrm{r}_{\text {outer }} \cdot \sqrt{\zeta}}$

177 where $\lambda_{\text {grout }}$ is the thermal conductivity of the grout $\left(\mathrm{W} / \mathrm{m}^{2} \cdot \mathrm{K}\right) ; \mathrm{r}_{\mathrm{EP}}$ is the radius of $\mathrm{EP}(\mathrm{m}) ; \zeta$ is the pipe number in the EP $(\mathrm{e} . \mathrm{g}$. for 178 a single U-tube pipe where there are two pipes in the borehole, $\zeta=2$ ). 


$$
\mathrm{R}_{\text {soil }}=\frac{1}{2 \pi \mathrm{L} \lambda_{\text {soil }}} \ln \frac{\mathrm{r}_{\text {soil }}}{\mathrm{r}_{\text {grout }}}
$$

181 where $\lambda_{\text {soil }}$ is the soil thermal conductivity $\left(\mathrm{W} / \mathrm{m}^{2} \cdot \mathrm{K}\right) ; \mathrm{r}_{\text {soil }}$ is the soil region radius $(\mathrm{m}) ; \mathrm{r}_{\text {grout }}$ is the grout radius (m).

$182 \quad 3.1 .2$ Heat pump power consumption

183 A parametric model is adopted to calculate the compressor power consumption with consideration of the influence of its rotation 184 speed by [46]:

$\mathrm{m}_{\mathrm{r}}=\mathrm{V}_{\mathrm{c}} \omega \rho_{\mathrm{r}, \text { suc }} \cdot\left[1+\mathrm{C}_{\mathrm{v}}\left(1-\frac{\mathrm{P}_{\mathrm{r}, \text { cond }}}{\mathrm{P}_{\mathrm{r}, \text { evap }}}\right)^{\frac{1}{\mathrm{n}}}\right]$

$\Delta \xi_{\text {comp }}=\xi_{\mathrm{r}, \text { dis }}-\xi_{\mathrm{r}, \text { suc }}=\frac{\mathrm{n}}{\mathrm{n}-1} \cdot \frac{\mathrm{P}_{\mathrm{r} \text {,evap }}}{\rho_{\mathrm{r}, \text { suc }}} \cdot\left[\left(\frac{\mathrm{P}_{\mathrm{r} \text {,ond }}}{\mathrm{P}_{\mathrm{r}, \text { evap }}}\right)^{\frac{\mathrm{n}-1}{\mathrm{n}}}-1\right]$

$187 \quad \mathrm{~W}_{\text {comp }}=\frac{\mathrm{m}_{\mathrm{r}} \Delta \mathrm{h}_{\text {comp }}}{\eta_{\text {comp }}}$

188 where $\mathrm{m}_{\mathrm{r}}$ is the compressor refrigerant mass flow rate $(\mathrm{kg} / \mathrm{s}) ; \mathrm{V}_{\mathrm{c}}$ is the compressor suction volume $\left(\mathrm{m}^{3}\right) ; \omega$ is the compressor rotational speed (rev/s); $\rho_{\mathrm{r}, \text { suc }}$ is the compressor suction refrigerant density $\left(\mathrm{kg} / \mathrm{m}^{3}\right) ; \mathrm{C}_{\mathrm{v}}$ is the compressor volumetric coefficient, $190 \mathrm{P}$ is the pressure $(\mathrm{kPa})$; $\xi$ is the specific enthalpy $(\mathrm{kJ} / \mathrm{kg}), \mathrm{n}$ is the polytropic compression coefficient; $\eta_{\text {comp }}$ is the compressor 191 mechanical efficiency; $\Delta \xi$ is the specific enthalpy change $(\mathrm{kJ} / \mathrm{kg}) ; \mathrm{W}_{\text {comp }}$ is the compressor power consumption ( $\left.\mathrm{kW}\right)$.

192 On the other hand, a circulation pump is used to keep the working fluid flowing in the EPs, its electricity consumption is added to the total energy usage of the GCHP system. The pressure drop in the EPs is calculated by using the friction factor in the Darcy

194 Weisbach equation [47], and can be given as:

195

$$
\Delta \mathrm{p}=\mathrm{f} \frac{\mathrm{L}}{\mathrm{D}_{\mathrm{H}}} \frac{\rho_{\text {fluid }} \mathrm{V}^{2}}{2}
$$

196 where V is the working fluid velocity in the EPs $(\mathrm{m} / \mathrm{s})$.

197 The power required by the circulation pump can be calculated as:

$$
\mathrm{W}_{\text {pump }}=\frac{\Delta \mathrm{p} \times \mathrm{m}}{\rho_{\text {fluid }} \eta / 100}
$$

199 where $\eta$ is the pump efficiency $(\%) ; \mathrm{m}$ is the mass flow rate in the EPs $(\mathrm{kg} / \mathrm{s})$. The fan power consumption in the air duct network 200 is very lower compared with the compressor's or circulation pump's, so it is not considered in this study.

$201 \quad 3.1 .3$ System performance

202 The system energy output includes the useful heating $\left(\mathrm{Q}_{\mathrm{h}}\right)$ and cooling energy $\left(\mathrm{Q}_{\mathrm{c}}\right)$. In heating mode, $\mathrm{Q}_{\mathrm{h}}$ is equal to $\left(\mathrm{Q}_{\mathrm{soil}}+\mathrm{W}_{\mathrm{comp}}\right.$ $\left.203+\mathrm{W}_{\text {pump }}\right)$ whereas in cooling mode, $\mathrm{Q}_{\mathrm{c}}$ is equal to $\left(\mathrm{Q}_{\text {soil }}-\mathrm{W}_{\text {comp }}-\mathrm{W}_{\text {pump }}\right)$. Furthermore, the key parameters to assess heat pump 
performance are the Coefficient of Performance (COP) in heating mode, and the Energy Efficiency Ratio (EER) in cooling mode,

which are given as:

$\mathrm{COP}=\frac{\mathrm{Q}_{\mathrm{h}}}{\mathrm{W}}=\frac{\mathrm{Q}_{\text {soil }}+\mathrm{W}_{\text {comp }}+\mathrm{W}_{\text {pump }}}{\mathrm{W}_{\text {comp }}+\mathrm{W}_{\text {pump }}}$

$$
\mathrm{EER}=\frac{\mathrm{Q}_{\mathrm{c}}}{\mathrm{W}}=\frac{\mathrm{Q}_{\text {soil }}-\mathrm{W}_{\text {comp }}-\mathrm{W}_{\text {pump }}}{\mathrm{W}_{\text {comp }}+\mathrm{W}_{\text {pump }}}
$$

\subsection{Economic analysis model}

The LCC is the sum of all expenses associated with an energy delivery system over a selected period or its service lifetime, with consideration of the time value of money. In the LCC, the expected future expenses are brought back to the present costs (discounted) through calculating how much have to be invested at a market discount rate. The LCC assessment process can be applied to evaluate financial benefit of the GCHP system with EPs, the main parameters, for example, interest rate, income tax rate, capital investment $(\mathrm{CI})$, loan payment (LP), system energy cost (SEC), maintenance cost (MC), periodic cost (PC), extra property tax (EPT), incoming tax savings (ITS), net present value (NPV) of money and cumulative EP system savings (EPS), are all evaluated in the LCC analysis. The LCC assessment of the GCHP system consists of seven parts: SEC, CI, LP, MC, PC, ITS and NPV, while the core part is the NPV calculation which is utilised to compare cash flows at different time intervals. The structure of the LCC assessment is shown in Fig.5.

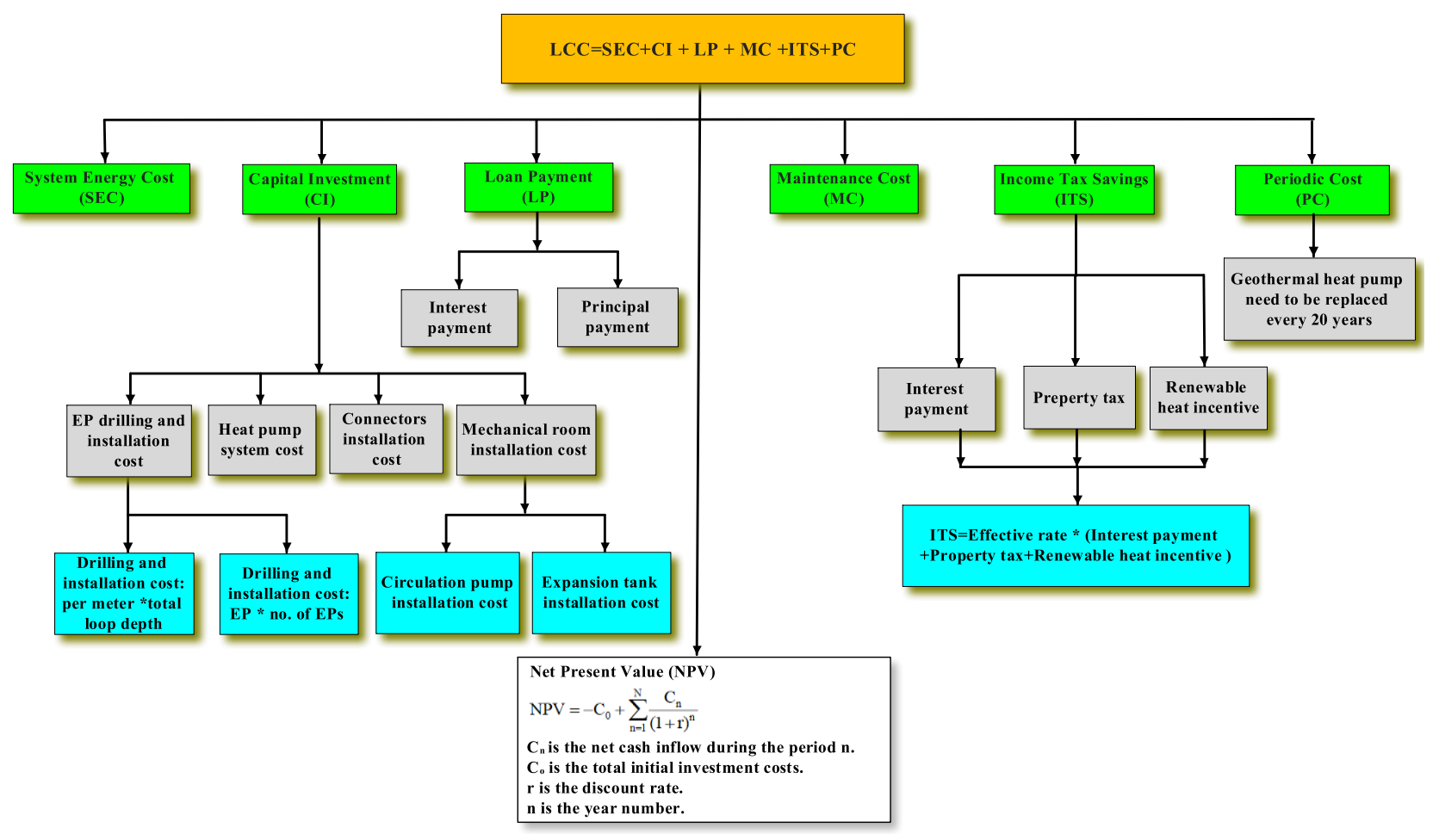

Fig.5. The LCC structure for GCHP with EPs 
According to the international standard of Environmental management BS ISO 15686 [48], the LCC refers to the systematic economic assessment of combined MC, CI, LP, SEC, PC and end-of-life costs of construction project during the whole life cycle period.

225 The LCC on the basis of the NPV for the GCHP system can be written as:

$226 \quad \mathrm{LCC}=\mathrm{C}_{\mathrm{SEC}}+\mathrm{C}_{\mathrm{Cl}}+\mathrm{C}_{\mathrm{LP}}+\mathrm{C}_{\mathrm{MC}}+\mathrm{C}_{\mathrm{ITS}}+\mathrm{C}_{\mathrm{PC}}$

where LCC is the GCHP system entire life cycle cost in NPV (£); $\mathrm{C}_{\mathrm{SEC}}$ is the GCHP system energy cost in PV (£); $\mathrm{C}_{\mathrm{CI}}$ is the GCHP system capital costs including the construction and engineering design expenses (£). In this study, only the construction expenses (installation and equipment expenses) are taken into account; $\mathrm{C}_{\mathrm{LP}}$ is the annual loan payment in $\mathrm{PV}(\mathfrak{£})$; $\mathrm{C}_{\mathrm{MC}}$ is the GCHP system maintenance cost in PV (£); $\mathrm{C}_{\mathrm{ITS}}$ is the GCHP system income tax savings expense in PV (£); $\mathrm{C}_{\mathrm{PC}}$ is the GCHP system periodic cost in PV (£).

\subsubsection{System boundary}

To obtain the precise LCC assessment results and provide the strongest protection for final evaluation, the foremost thing is to determine system boundary including its scope and lifetime. The scope of the GCHP system composes of high density polyethylene U-tube pipes, EPs, heat pump unit, fan coils and circulating pumps. According to the studies [40, 41, 48], the lifetime of the polyethylene U-tube pipe is approximately 50 years. On the other hand, the service lifetime of the heat pump system could be approximately 20 years. Thereby, the 20 years' service lifetime of the GCHP system is adopted for the LCC evaluation.

\subsubsection{System energy cost (SEC)}

The SEC is also known as the fuel cost saving which is determined based on the electricity price and consumption. The electricity consumption of the system depends on heating and cooling loads of the building. The annual SEC is given as:

$\mathrm{C}_{\mathrm{SEC}}=\mathrm{c}_{\mathrm{SEC}} \times \frac{1}{\left(1+\mathrm{d}_{\mathrm{SEC}}\right)^{\mathrm{N}}}$

$\mathrm{c}_{\mathrm{SEC}}=\mathrm{E}_{\text {generation }} \cdot \beta$

where $\mathrm{C}_{\mathrm{SEC}}$ is the GCHP system energy cost in PV (£); $\mathrm{c}_{\mathrm{SEC}}$ is the GCHP annual electricity cost ( $£$ ); $\mathrm{d}_{\mathrm{SEC}}$ is the inflation rate of electricity price $(\%) ; \mathrm{N}$ is the period of economic assessment; Egeneration is the energy generation (heating and cooling) from the GCHP system $(\mathrm{kWh}) ; \beta$ is the electricity price $(£ / \mathrm{kWh})$. 
3.2.1.3 Capital investment (CI)

251 The high expenses of the system are for drilling and high density polyethylene pipe material, then followed by the heat pump 252 with a mean cost of $£ 5,600$ for a capacity of $5.9 \mathrm{~kW}$ [41]. The other costs are comparatively low, for instance, the expenses of 253 installing header pipes, circulation pump and expansion tank, and fittings [28].

254 The CI model is established based on three cost categories as follows:

$255 \quad \mathrm{CI}=\mathrm{C}_{\mathrm{ic}}+\mathrm{C}_{\mathrm{in}}+\mathrm{C}_{\mathrm{co}}$

where $C_{i c}$ is the initial expense of main equipment $(£)$; $C_{i n}$ is the installation expense, labour expense, auxiliary equipment

257 expense $(\mathfrak{f}) ; \mathrm{C}_{\mathrm{co}}$ is the commissioning or subscription expense $(\mathfrak{f})$.

$258 \quad$ 3.2.1.4 Loan payment (LP)

259 The LP is also referred to as the mortgage payment per annum which involves principle and interest payments to install the 260 system.

261 The PV of LP is given by:

$262 \quad \mathrm{C}_{\mathrm{LP}}=\mathrm{G} \cdot \frac{\mathrm{r}_{\mathrm{LP}} \cdot\left(1+\mathrm{r}_{\mathrm{LP}}\right)^{\mathrm{z}}}{\left(1+\mathrm{r}_{\mathrm{LP}}\right)^{\mathrm{z}}-1}$

where $\mathrm{C}_{\mathrm{LP}}$ is the loan payment per annum (£); $\mathrm{G}$ is the principal payment $(\mathfrak{f}) ; \mathrm{r}_{\mathrm{LP}}$ is the yearly interest rate $(\%)$; $\mathrm{z}$ is the number

264 of loan payment years.

265 3.2.1.5 Maintenance cost (MC)

266 The annual MC includes expected and unexpected budgets that are associated with the repair and corrective maintenance of the 267 system. The present worth of MC per annum is given by:

$\mathrm{C}_{\mathrm{MC}}=\mathrm{c}_{\mathrm{MC}} \times \frac{1}{\left(1+\mathrm{d}_{\mathrm{MC}}\right)^{\mathrm{k}}}$

269 where $\mathrm{C}_{\mathrm{MC}}$ is the present worth of the $\mathrm{k}^{\text {th }}$ year GCHP maintenance expense $(\mathfrak{f})$; $\mathrm{c}_{\mathrm{MC}}$ is the first year maintenance expense of $270 \mathrm{GCHP}(\mathfrak{f}) ; \mathrm{d}_{\mathrm{MC}}$ is the inflation rate of maintenance $(\%) ; \mathrm{k}$ is the period of maintenance payment.

271 3.2.1.6 Periodic cost (PC)

272 The PC denotes the replacement cost of main system parts. For the GCHP system, only the heat pump is required to be replaced 273 every 20 years $[41,49,50]$. Therefore, the PC in PV is written as:

$274 \quad \mathrm{C}_{\mathrm{PC}}=\mathrm{c}_{\mathrm{PC}} \times \frac{1}{\left(1+\mathrm{d}_{\mathrm{PC}}\right)^{\mathrm{s}}}$

275 where $\mathrm{C}_{\mathrm{PC}}$ is the present worth of the $\mathrm{s}^{\text {th }}$ year GHCP system periodic expense (£); $\mathrm{c}_{\mathrm{PC}}$ is the first year GCHP system periodic expense $(\mathfrak{f}) ; \mathrm{d}_{\mathrm{PC}}$ is the inflation rate of replacement $(\%)$; $\mathrm{s}$ is the year number of periodic payment. 
277 In fact, the PC of the GCHP system is not considered in this study because the heat pump only needs to be replaced every 20 278 years.

279 3.2.1.7 EP system savings (EPS) and income tax savings (ITS)

280 The EPS is also referred to as the yearly net cash flow and can be written as $[49,50]$ :

$$
\mathrm{C}_{\mathrm{EPS}}=\mathrm{C}_{\mathrm{SEC}}-\mathrm{C}_{\mathrm{LP}}-\mathrm{C}_{\mathrm{MC}}-\mathrm{C}_{\mathrm{PC}}-\mathrm{C}_{\mathrm{EPT}}+\mathrm{C}_{\mathrm{ITS}}
$$

where $\mathrm{C}_{\mathrm{EPT}}$ is the extra property tax $(\mathfrak{f})$; $\mathrm{C}_{\mathrm{ITS}}$ is the income tax savings $(\mathfrak{f})$.

The $\mathrm{C}_{\mathrm{EPT}}$ in PV is expressed as:

$$
\mathrm{C}_{\mathrm{EPT}}=\mathrm{c}_{\mathrm{EPT}} \times \frac{1}{\left(1+\gamma_{\mathrm{EPT}}\right)^{\alpha}}
$$

where $\mathrm{c}_{\mathrm{EPT}}$ is the annual extra property tax cost of the GCHP system (£); $\gamma_{\mathrm{EPT}}$ is the inflation rate of extra property tax $(\%)$; $\alpha$ is the period of extra property tax.

The $\mathrm{C}_{\mathrm{ITS}}$ in $\mathrm{PV}$ is given by $[49,50]$ :

$\mathrm{C}_{\mathrm{ITS}}=\mathrm{C}_{\mathrm{ETR}} \times\left(\mathrm{C}_{\mathrm{IP}}+\mathrm{C}_{\mathrm{EPT}}+\mathrm{C}_{\mathrm{RHI}}\right)$

where $\mathrm{C}_{\mathrm{ETR}}$ is the effective tax rate $(\%) ; \mathrm{C}_{\mathrm{IP}}$ is the interest payment $(\mathfrak{f}) ; \mathrm{C}_{\mathrm{RHI}}$ is the renewable heat incentive bonus for heat generation in the UK $(£)$.

$291 \quad 3.2 .1 .8$ Net present value (NPV) the NPV is written by the following equation:

$294 \quad \mathrm{NPV}=-\mathrm{C}_{\mathrm{CI}}+\sum_{\mathrm{N}=1}^{\mathrm{N}^{\prime}} \frac{\mathrm{C}_{\mathrm{N}}}{(1+\mathrm{r})^{\mathrm{N}}}$

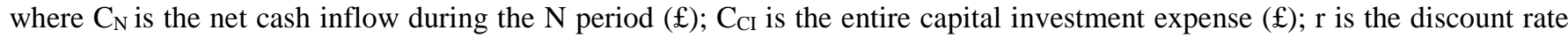
$(\%)$.

A positive NPV demonstrates that the projected earning created by a project or investment surpasses the expected cost. Generally, an investment with a positive NPV will be profitable, and an investment with a negative NPV will cause a net loss.

\subsection{LCC simulation process}

The implementation of the LCC is done by the @ Risk software, which is coupled with Microsoft Excel. The whole analysis is split into six parts and the LCC assessment flowchart is shown in Fig.6. Some critical parameters and economic equations are needed, such as the system scope, system functional component, CI value, building heating/cooling loads, heat pump specifications and number of iterations for each step. The $\mathrm{C}_{\mathrm{SEC}}, \mathrm{C}_{\mathrm{LP}}, \mathrm{C}_{\mathrm{MC}}, \mathrm{C}_{\mathrm{EPS}}, \mathrm{C}_{\mathrm{EPT}}$ and $\mathrm{C}_{\mathrm{ITS}}$ are obtained by using Eqs. (22), (23), (25), (26) and (28) - (30). And then, the NPV and payback period are defined as the output parameters. Meanwhile, the 
input parameter distribution is defined by using the Normal function. Specifically, the ranges of the capital cost, energy generation and electricity price are from $£ 6,500$ to $£ 15,000,13,000 \mathrm{kWh}$ to $24,000 \mathrm{kWh}$, and $£ 0.075 / \mathrm{kWh}$ to $£ 0.22 / \mathrm{kWh}$, respectively. In the following, the number of iteration is set as 6000 in this simulation process. Once the programmed cycles of iterations are finished, the NPV and payback period are obtained.

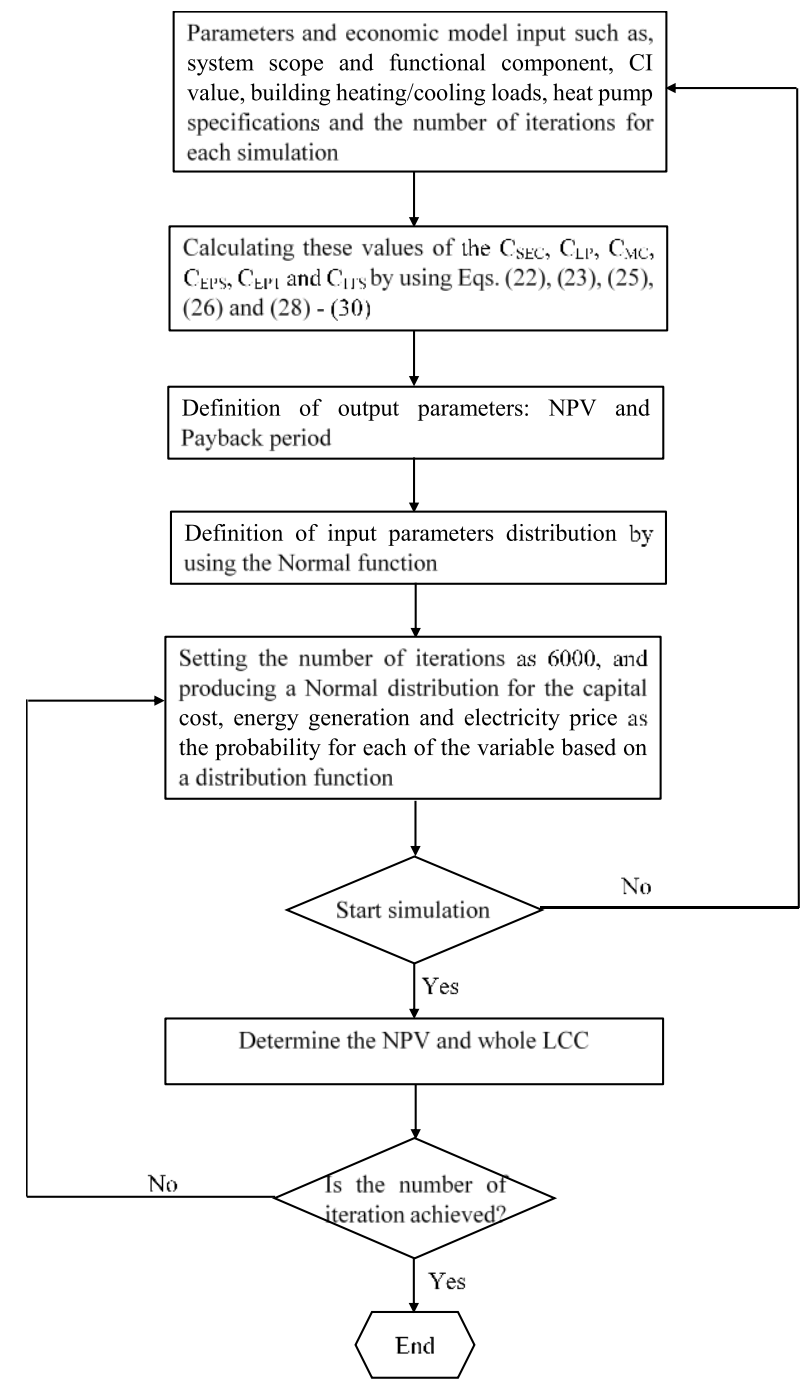

Fig.6. The flowchart of LCC assessment for GCHP with EPs

\section{Results and discussion}

Before the 2D numerical model is employed to simulate the system energy performance, the model validation is implemented by comparing numerical results with the experimental data $[39,40]$. The COPs of the numerical and experimental results are presented in Fig.7 (a), and it is found that the maximum COP difference between them is approximately $8.33 \%$ noticed in November. Likewise, the EERs of the numerical and experimental data are displayed in Fig.7 (b), and the maximum EER difference is about $8.17 \%$ noticed in May. Therefore, the simulation results are effectively supported by the experimental data, so the 2D numerical model can be utilized to study the energy performance of the GSHP with multiple EPs. 

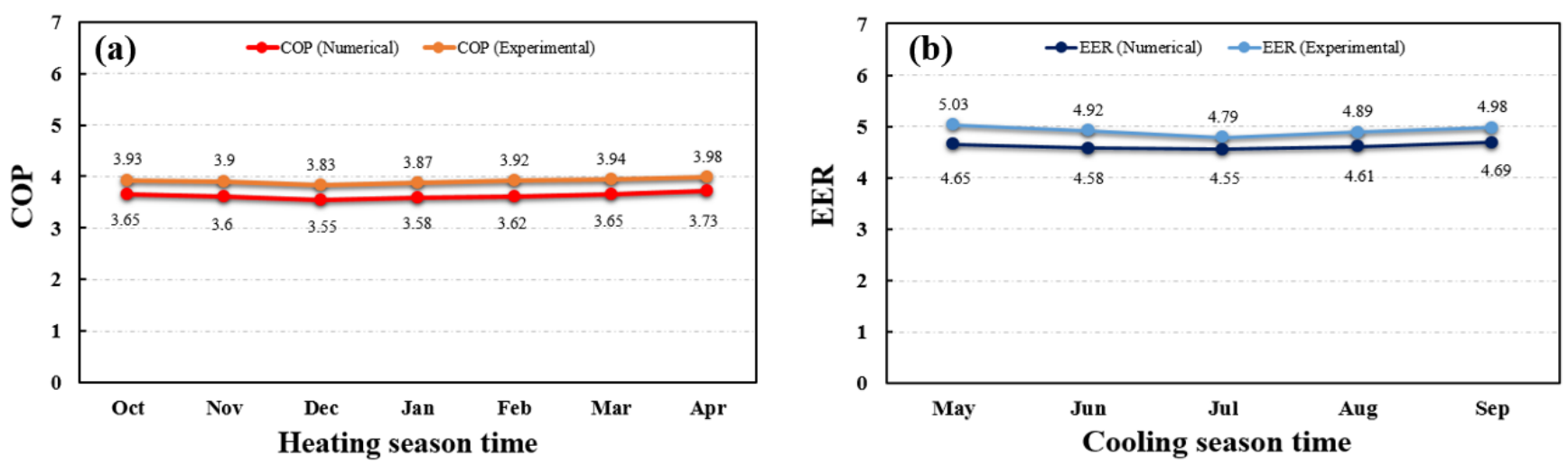

Fig.7. Comparisons between numerical results and experimental data: (a) COP; (b) EER

\subsection{Energy performance}

The annual operating process of the GCHP system is classified into two periods on the basis of the local climate condition. One is the heating season from October/2007 to April/2008. Another is the cooling season from May/2008 to September/2008. The mean system energy output from the heat pump (heating and cooling) and ground energy obtained (extracted and rejected) are simulated and given in Fig. 8. In this figure, the monthly thermal energy generations are lower in October and April. It is noteworthy that the minimum monthly energy output of the GCHP system is approximately 1,593.94 kWh in April whereas the maximum value is approximately 2,285.24 kWh in December. Moreover, from February to April, the GCHP system operates in most of time, therefore the soil has no enough time to recover. So the soil temperature nearby the EP is comparatively low, which results in a low temperature working fluid temperature entering into the evaporator of the heat pump unit, correspondingly a low COP. Meanwhile, the minimum value of monthly heat extracted from the ground is about 1,148.99 kWh in April, and the maximum value is about $1,890.20 \mathrm{kWh}$ in December. The minimum GCHP system cooling output is about $1,000.25 \mathrm{kWh}$ in September whereas the maximum value is about $1,521.78 \mathrm{kWh}$ in July. Furthermore, the monthly heat rejected into the soil is also depicted, the minimum rejected heat is about $894.85 \mathrm{kWh}$ in September whereas the maximum value is about $1,279.01 \mathrm{kWh}$ in July.
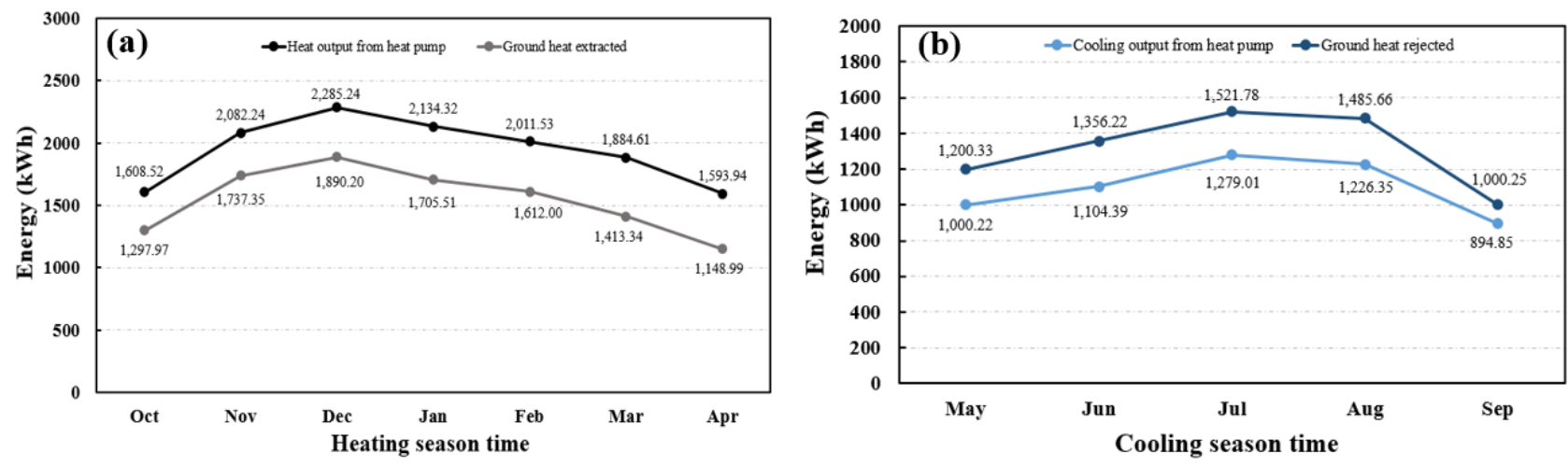

Fig.8. Energy output: (a) in the heating season; (b) in the cooling season 

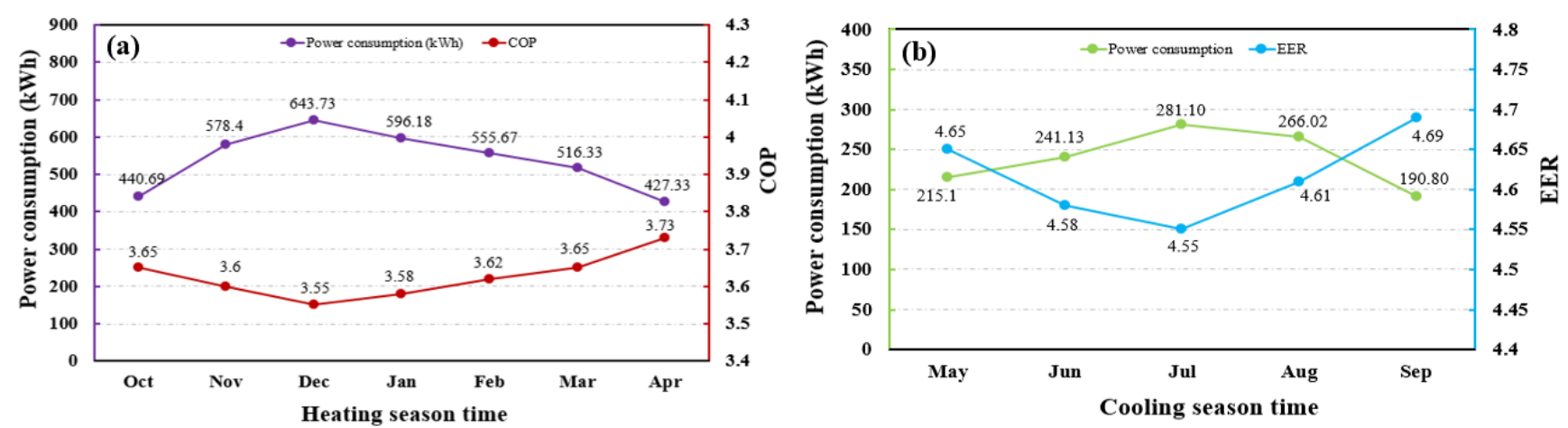

Fig.9. Electrical energy consumption and system performance: (a) in the heating season; (b) in the cooling season

The monthly electrical energy consumption and system performance in the heating and cooling seasons are shown in Fig.9. The system can fulfil the building energy demands under both operating conditions. The monthly heating electrical energy consumptions of the GCHP system are $440.69 \mathrm{kWh}, 578.40 \mathrm{kWh}, 643.73 \mathrm{kWh}, 596.18 \mathrm{kWh}, 555.67 \mathrm{kWh}, 516.33 \mathrm{kWh}$ and 427.33 kWh from October to April, with corresponding average monthly COPs reach 3.65, 3.6, 3.55, 3.58, 3.62, 3.65 and 3.73, respectively. Therefore, the system annual average COP is 3.63. The monthly cooling electrical energy consumptions are 215.10 $\mathrm{kWh}, 241.13 \mathrm{kWh}, 281.10 \mathrm{kWh}, 266.02 \mathrm{kWh}$ and $190.80 \mathrm{kWh}$ from May to September, with corresponding average monthly EERs achieve 4.65, 4.58, 4.55, 4.61 and 4.69, respectively. So the system annual average EER is 4.62 .

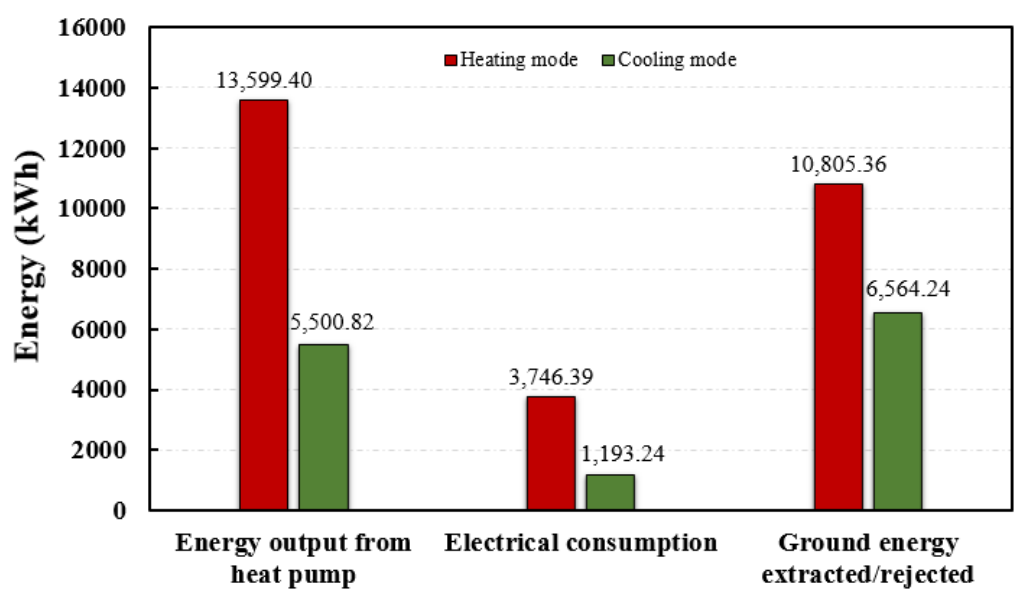

Fig.10. Annual total energy generation, electrical energy consumption and ground energy extracted/rejected According to Fig.10, the total heat output of the GCHP system is approximately $13,599.40 \mathrm{kWh}$ and the heat extracted from soil is about 10,805.36 kWh, leading to the power consumption of around 3,746.39 $\mathrm{kWh}$. By comparison, the cooling output is around $5,500.82 \mathrm{kWh}$ and the heat rejected into the soil is approximately $6,564.24 \mathrm{kWh}$, resulting in $1,193.24 \mathrm{kWh}$ of the power consumption. Therefore, the annual energy output (heating and cooling) of the GCHP system is estimated to be about 19,100 $\mathrm{kWh}$ and the total power consumption reaches approximately 4,939.63 kWh. So the energy provided by the GCHP system can cover the building heating and cooling requirements. 
4.2 Economic assessment

The total system capital cost is $£ 9,033$ with $10 \%$ down payment, the remaining part of the initial expense is financed at an interest rate of $8.2 \%$ for the 20 years' period. It is anticipated to pay normal maintenance expense for the system annually with an inflation rate of $4.5 \%$ [50]. Energy pricing mechanism in the UK is a combination of regulated and market-driven prices [30]. The electricity price is $£ 0.1097 / \mathrm{kWh}$ by the UK government [51]. In the light of UK energy prices regulated via Ofgem [52], the RHI rate for the units between $4 \mathrm{~kW}$ and $10 \mathrm{~kW}$ is $£ 0.1986 / \mathrm{kWh}$. The property tax is $2 \%$ of the initial cost. The maintenance expense for EPs is estimated to be $£ 150$ per annum. The average effective income tax rate is evaluated to be $20 \%$ over the service lifetime period. The costs of EPs include the auger drilling, high density polyethylene pipe material, installation and maintenance costs, are given in Table 4. Details of the component prices, economic expenses and parameters are illustrated in Table 5.

Table 4 Cost breakdown of GCHP system [39]

\begin{tabular}{ll}
\hline Item & Value \\
\hline EP pipe & \\
Pipe drilling cost & $£ 2.63 / \mathrm{m} \times 413 \mathrm{~m}$ \\
Loop installation into pile reinforcement cages & $£ 640$ \\
Estimated pipe installation cost & $£ 1,726$ \\
Heat pump system & \\
Heat pump \& commissioning & $£ 5,600$ \\
Working fluid cost & $£ 174$ \\
Estimated heat pump unit cost & $£ 5,774$ \\
Other equipment installation & \\
Header circuit insulation & $£ 186$ \\
Brass fittings & $£ 386$ \\
4 port brass manifold with flow control & $£ 361$ \\
Estimated other equipment cost & $£ 933$ \\
Labour cost & \\
Header circuit labour & $£ 600$ \\
Total capital cost & $£ 9,033$ \\
Estimated maintenance cost & $£ 150$ \\
\hline
\end{tabular}

Table 5 Parameters used for economic analysis

\begin{tabular}{ll}
\hline Item & Value \\
\hline Electricity price & $£ 0.1097 / \mathrm{kWh}$ \\
RHI for GCHP & $£ 0.1986 / \mathrm{kWh}$ \\
Down payment & $10 \%$ \\
Inflation rate of electricity price & $6 \%$ \\
Interest rate of principal & $8.2 \%$ \\
Inflation rate of maintenance & $4.5 \%$ \\
Council rate for property tax & $2 \%$ \\
Inflation rate of extra property tax & $4 \%$ \\
Income tax rate & $20 \%$ \\
UK discount rate & $8.75 \%$ \\
\hline
\end{tabular}

367 The annual progressions of SEC and MC of the GCHP system for the 20-year operating period are presented in Table 6. The system annual fuel saving bill is the previous year's expense multiplied by inflation rate of electricity price. Specifically, the 
SEC for the first year is approximately $£ 2,095.27(19,100 \mathrm{kWh} \times £ 0.1097 / \mathrm{kWh})$ and the second year's SEC is about $£ 2,220.99$ $[19,100 \mathrm{kWh} \times £ 0.1097 / \mathrm{kWh} \times(1+6 \%)]$ with considering the inflation rate of electricity price. By the end of the $20^{\text {th }}$ year, the value can reach $£ 6,339.45\left[19,100 \mathrm{kWh} \times £ 0.1097 / \mathrm{kWh} \times(1+6 \%)^{19}\right]$. Similarly, the MC in the first year and $20^{\text {th }}$ year achieve $£ 150$ and $£ 346.18$, respectively. Moreover, the annual progressions of LP, interest payment, remaining principal, EPS and ITS are also shown in Table 6. For example, the interest payment in the first year is $£ 666.64(8.2 \% \times £ 8,129.7)$. The LP is approximately $£ 840.39$ by using Eq. (25), thereby the principal payment and remaining principal reach $£ 173.75$ ( $£ 840.39$ $£ 666.64)$ and $£ 7,955.95(£ 9,033 \times 10 \%$ - $£ 173.75)$, respectively. In terms of the ITS and EPS, the progressions of the ITS and EPS for the 20-year operating period are given in columns 10 and 11 , to be more specific, the ITS for the first year and $20^{\text {th }}$ year are approximately $£ 928.11$ and $£ 847.51$, respectively. Moreover, the EPS for each year is the sum of the items including SEC, LP, MC, EPT and ITS. The annual EPS is brought to present worth using the UK market discount rate of $8.75 \%$. The deposit charge is $£ 903.3$ which is a negative present value, and it is displayed as Year 0. The EPS becomes a positive value reaching approximately $£ 1,852.33$ after the first year and the EPS achieves $£ 5,619.77$ until the $20^{\text {th }}$ year. Furthermore, the NPV of the GCHP system is obtained approximately $£ 26,095.14$ at the market discount rate of $8.75 \%$ for a 20 -year operating period. The economic assessment demonstrates that the cash flow turns positive at the end of the first year and maintains positive permanently by the end of the service lifetime. This is because the replacement of the heat pump is only considered in the $20^{\text {th }}$ year, meanwhile, the original and maintenance expenses of the GCHP system are much less as well in this case.

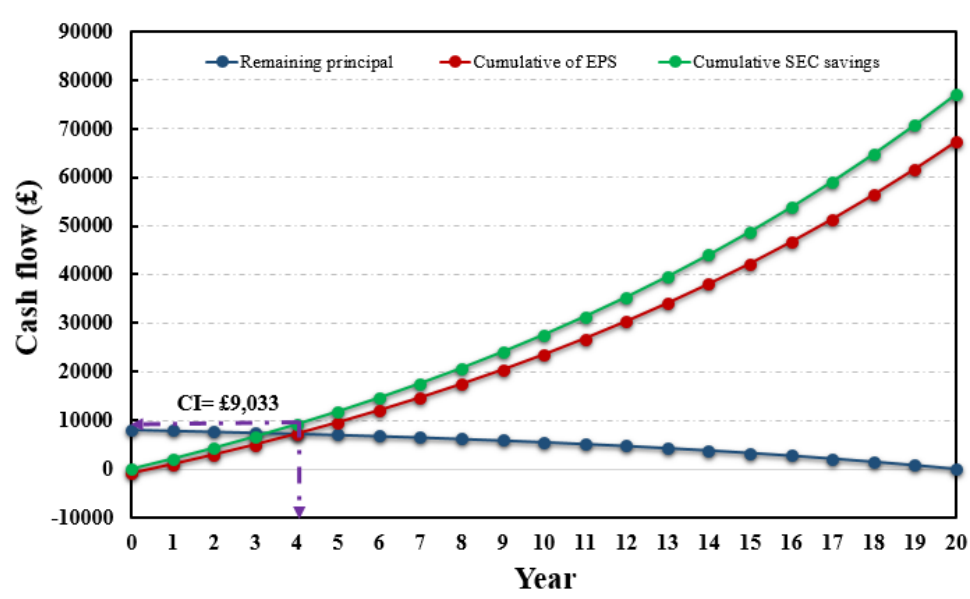

Fig.11. Variation of remaining principal, cumulative EPS and cumulative SEC savings

According to Fig.11, the cumulative SEC saving $(£ 9,166)$ exceeds the CI $(£ 9,033)$ by the end of the fourth year. The cumulative EPS becomes positive after one year due to the low capital and little maintenance costs. The cumulative system saving $(£ 9,531.53)$ surpasses the remaining principal balance $(£ 7,106.28)$ by the end of the fifth year. The calculation process of the LCC analysis is given in Table 6. Meanwhile, the payback period is approximately 4.3 years as shown in Fig.11. This is deemed an acceptable payback period ( $<10$ years) for an engineering project of this nature, and serves to demonstrate the clear benefit of adopting such a system in the UK context. 
394 Table 6 The economic assessment of the GCHP with multiple EPs system for Birmingham, UK (20-year service lifetime)

\begin{tabular}{|c|c|c|c|c|c|c|c|c|c|c|c|c|c|}
\hline Year & $\begin{array}{l}\text { Energy } \\
\text { generation } \\
\text { (kWh/year) }\end{array}$ & SEC (£) & $\mathbf{L P}(\mathfrak{E})$ & $\begin{array}{l}\text { Interest } \\
\text { payment } \\
(\mathfrak{f})\end{array}$ & $\begin{array}{l}\text { Principal } \\
\text { payment } \\
(\mathfrak{f})\end{array}$ & $\begin{array}{l}\text { Remaining } \\
\text { principal } \\
\text { (f) }\end{array}$ & MC (£) & EPT (£) & ITS (£) & EPS (£) & $\begin{array}{l}\text { Present } \\
\text { worth of } \\
\text { EPS (£) }\end{array}$ & $\begin{array}{l}\text { Cumulative } \\
\text { EPS (£) }\end{array}$ & $\begin{array}{l}\text { Cumulative } \\
\text { SEC } \\
\text { savings (£) }\end{array}$ \\
\hline 0 & & & & & & $8,192.70$ & & & & $(903.30)$ & $(903.30)$ & $(903.30)$ & \\
\hline 1 & 19,100 & $2,095.27$ & $(840.39)$ & 666.64 & 173.75 & $7,955.95$ & $(150)$ & $(180.66)$ & 928.11 & $1,852.33$ & $1,703.29$ & 949.03 & $2,095.27$ \\
\hline 2 & 19,100 & $2,220.99$ & $(840.39)$ & 652.39 & 188.00 & $7,767.94$ & $(156.75)$ & $(187.89)$ & 926.70 & $1,962.67$ & $1,659.54$ & $2,911.69$ & $4,316.26$ \\
\hline 3 & 19,100 & $2,354.25$ & $(840.39)$ & 636.97 & 203.42 & $7,564.52$ & $(163.80)$ & $(195.40)$ & 925.13 & $2,079.78$ & $1,617.07$ & $4,991.47$ & $6,670.50$ \\
\hline 4 & 19,100 & $2,495.50$ & $(840.39)$ & 620.29 & 220.10 & $7,344.43$ & $(171.18)$ & $(203.22)$ & 923.35 & $2,204.07$ & $1,575.83$ & $7,195.55$ & $9,166.00$ \\
\hline 5 & 19,100 & $2,645.23$ & $(840.39)$ & 602.24 & 238.15 & $7,106.28$ & $(178.88)$ & $(211.35)$ & 921.37 & $2,335.99$ & $1,535.76$ & $9,531.53$ & $11,811.23$ \\
\hline 6 & 19,100 & $2,803.94$ & $(840.39)$ & 582.71 & 257.68 & $6,848.60$ & (186.93) & $(219.80)$ & 919.16 & $2,475.98$ & $1,496.83$ & $12,007.51$ & $14,615.18$ \\
\hline 7 & 19,100 & $2,972.18$ & $(840.39)$ & 561.59 & 278.80 & $6,569.80$ & $(195.34)$ & $(228.59)$ & 916.69 & $2,624.55$ & $1,458.98$ & $14,632.06$ & $17,587.36$ \\
\hline 8 & 19,100 & $3,150.51$ & $(840.39)$ & 538.72 & 301.67 & $6,268.13$ & (204.13) & $(237.74)$ & 913.94 & $2,782.19$ & $1,422.18$ & $17,414.26$ & $20,737.87$ \\
\hline 9 & 19,100 & $3,339.54$ & $(840.39)$ & 513.99 & 326.40 & $5,941.73$ & $(213.32)$ & $(247.25)$ & 910.89 & $2,949.49$ & $1,386.38$ & $20,363.75$ & $24,077.41$ \\
\hline 10 & 19,100 & $3,539.92$ & $(840.39)$ & 487.22 & 353.17 & $5,588.56$ & $(222.91)$ & $(257.14)$ & 907.52 & $3,126.99$ & $1,351.56$ & $23,490.75$ & $27,617.32$ \\
\hline 11 & 19,100 & $3,752.31$ & $(840.39)$ & 458.26 & 382.13 & $5,206.43$ & $(232.95)$ & $(267.42)$ & 903.79 & $3,315.34$ & $1,317.67$ & $26,806.09$ & $31,369.63$ \\
\hline 12 & 19,100 & $3,977.45$ & $(840.39)$ & 426.93 & 413.46 & $4,792.97$ & $(243.43)$ & (278.12) & 899.66 & $3,515.17$ & $1,284.68$ & $30,321.26$ & $35,347.08$ \\
\hline 13 & 19,100 & $4,216.10$ & $(840.39)$ & 393.02 & 447.37 & $4,345.60$ & $(254.38)$ & $(289.24)$ & 895.11 & $3,727.19$ & $1,252.57$ & $34,048.45$ & $39,563.18$ \\
\hline 14 & 19,100 & $4,469.06$ & $(840.39)$ & 356.34 & 484.05 & $3,861.55$ & $(265.83)$ & $(300.81)$ & 890.08 & $3,952.11$ & $1,221.29$ & $38,000.56$ & $44,032.24$ \\
\hline 15 & 19,100 & $4,737.20$ & $(840.39)$ & 316.65 & 523.74 & $3,337.81$ & $(277.79)$ & $(312.84)$ & 884.55 & $4,190.73$ & $1,190.83$ & $42,191.29$ & $48,769.44$ \\
\hline 16 & 19,100 & $5,021.44$ & $(840.39)$ & 273.70 & 566.69 & $2,771.12$ & $(290.29)$ & $(325.36)$ & 878.46 & $4,443.86$ & $1,161.16$ & $46,635.15$ & $53,790.88$ \\
\hline 17 & 19,100 & $5,322.72$ & $(840.39)$ & 227.23 & 613.16 & $2,157.96$ & $(303.36)$ & $(338.37)$ & 871.77 & $4,712.38$ & $1,132.25$ & $51,347.52$ & $59,113.60$ \\
\hline 18 & 19,100 & $5,642.09$ & $(840.39)$ & 176.95 & 663.44 & $1,494.53$ & $(317.01)$ & $(351.91)$ & 864.42 & $4,997.21$ & $1,104.08$ & $56,344.73$ & $64,755.69$ \\
\hline 19 & 19,100 & $5,980.61$ & $(840.39)$ & 122.55 & 717.84 & 776.69 & $(331.27)$ & $(365.98)$ & 856.36 & $5,299.32$ & $1,076.63$ & $61,644.05$ & $70,736.30$ \\
\hline 20 & 19,100 & $6,339.45$ & $(840.39)$ & 63.69 & 776.70 & -0.015 & $(346.18)$ & $(380.62)$ & 847.51 & $5,619.77$ & $1,049.86$ & $67,263.82$ & $77,075.75$ \\
\hline Total & & & & & & & & & & & $26,095.14$ & & \\
\hline
\end{tabular}


4.3 Sensitive analyses of NPV and payback period

397 In the following, the comparison analyses are implemented with respect to the NPV and payback period with different parameters.

398 The distribution graphs of cumulative probability versus NPV and payback time for the GCHP system over the whole LCC period are presented in Figs.12 and 13 respectively. The legend gives the minimum, maximum, average, number of iterations and standard deviation of NPV and payback period in this case.

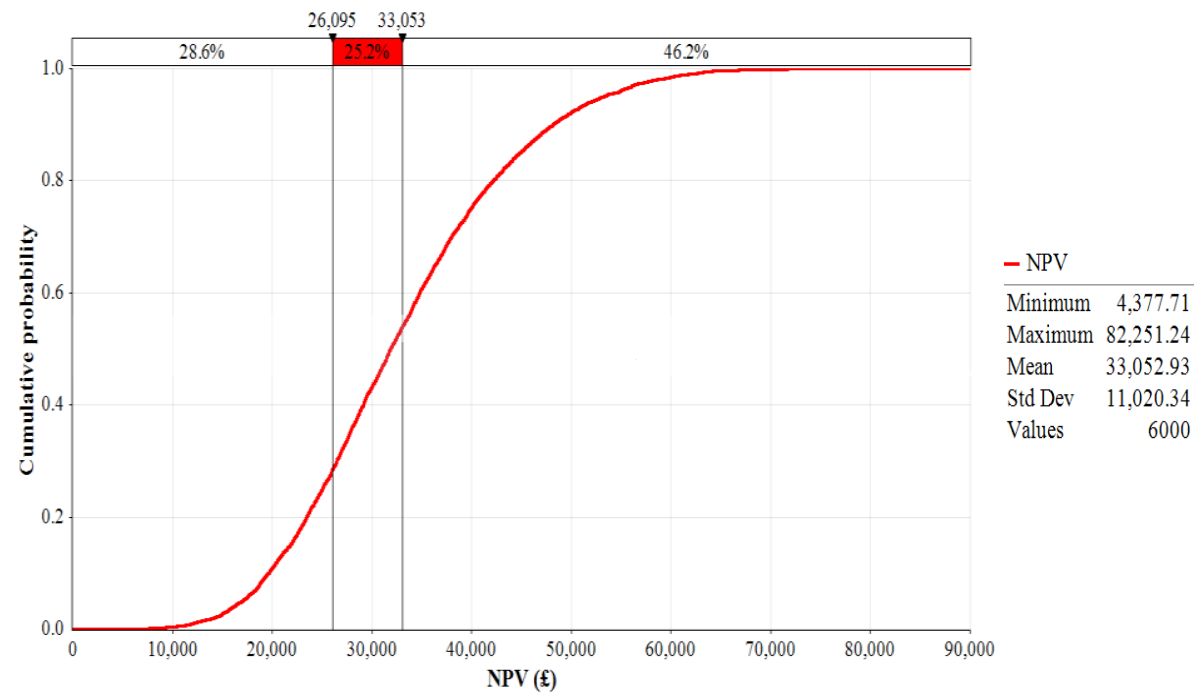

Fig.12. NPV distribution

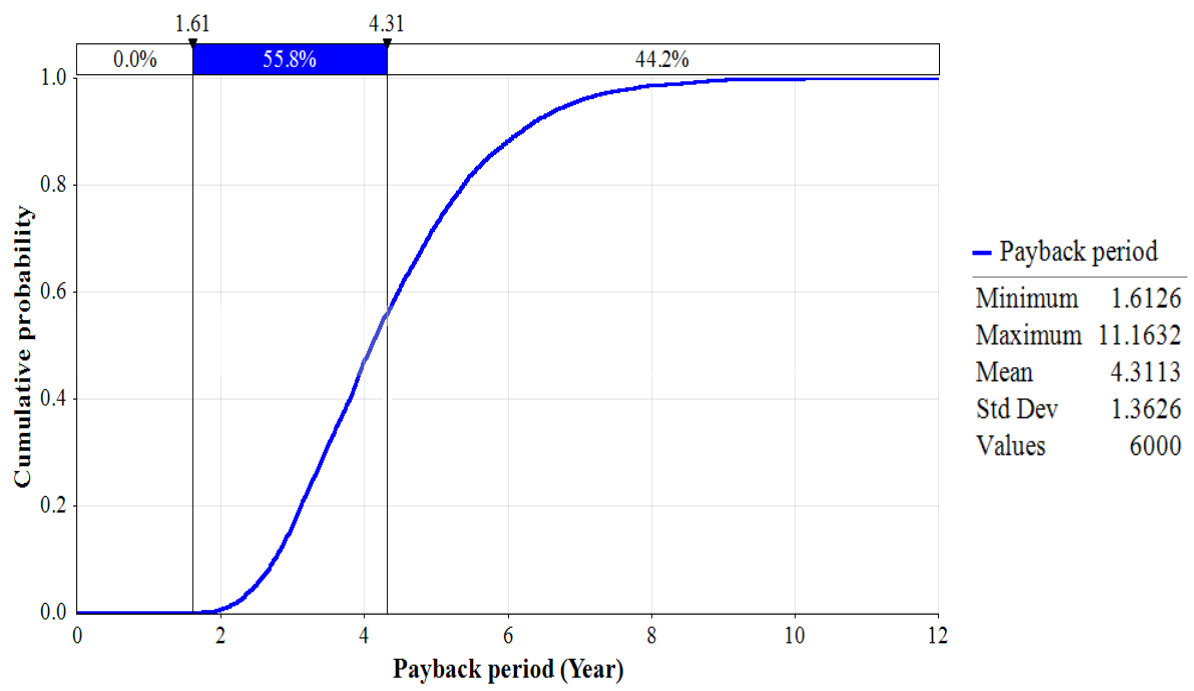

Fig.13. Payback period distribution

The vertical lines in Fig.12 represent the NPV of present case $(£ 26,095)$ and average value $(£ 33,053)$. One row of percentages on the top of the diagram displays the probabilities relative to the NPV. Specifically, the top row depicts the probability regarding the LCC of the GCHP system which is classified into three categories. When the NPV is less than the present case value, it accounts for $28.6 \%$; when the NPV is located between the NPV of the present case value and average value, it makes up 25.2\%; when the NPV is greater than the average value, it accounts for a proportion of $46.2 \%$. By comparison, the vertical lines in Fig. 12 
denote the minimum and average values in the payback period. Based on one row of percentages on the top of the graph, there is a probability of $44.2 \%$ that the payback period of the system is more than 4.31 years, and $55.8 \%$ of the payback time is between 1.61 and 4.31 years, while $0 \%$ of the payback period is less than 1.61 years.

The NPV variations with the uncertain input factors are shown in Fig.14. It is denoted that the uncertainty associated with electricity price has the largest effect on the NPV whereas the inflation rate of maintenance cost has the least impact among the uncertain input parameters. Notably, the low electricity price makes the NPV to be $£ 20,308.66,38.6 \%$ lower compared to the baseline of $£ 33,068.19$. On the contrary, the high electricity price makes the NPV as high as $£ 49,255.99$ (50.0\% higher). Similarly, the uncertainty in energy generation is closely related to the variety of financial credits achieved from improving the NPV. Thus, the range of energy generation by using the GCHP system results in a NPV variation of approximately $£ 23,078.62$ - $£ 42,588.94$. If the lower capital investment were obtained, the NPV would reach about $£ 36,816.40$ while the higher capital investment induces a longer period to achieve a positive NPV of $£ 28,663.53$ (i.e. a longer payback period).

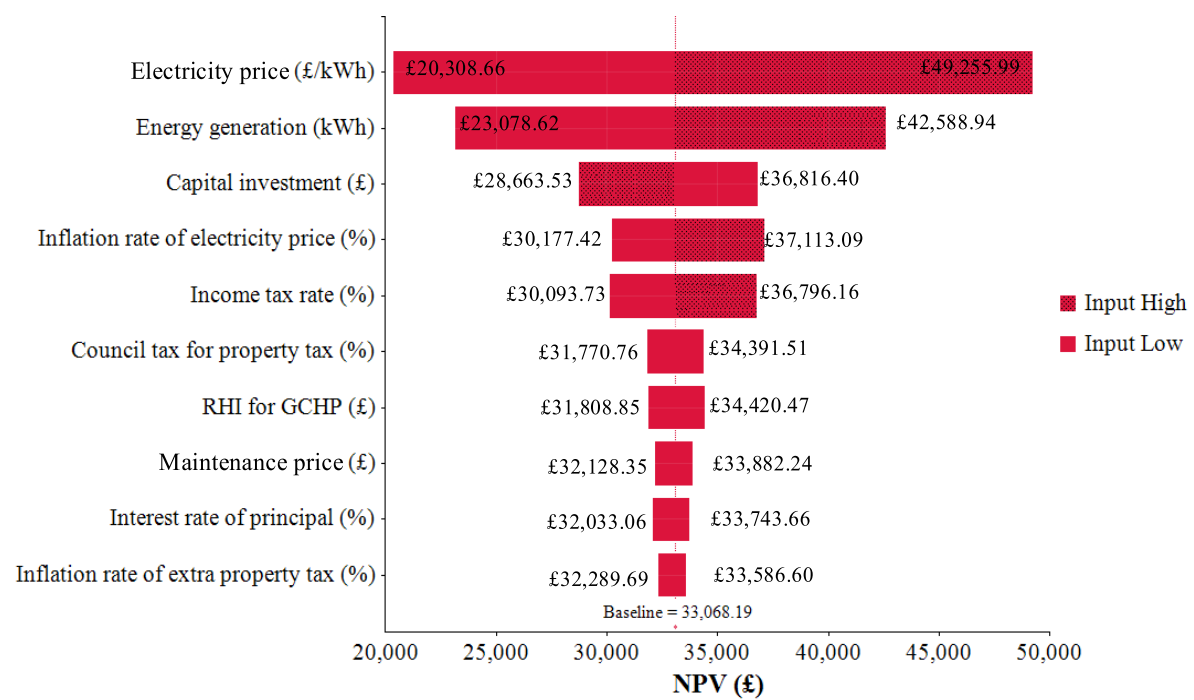

Fig.14. Tornado chart of NPV variation with uncertain input parameters

The NPV variations against electricity price, energy generation, capital cost and discount rate are presented in Fig.15. The horizontal and vertical lines (respective mean values) split the graph into four quadrants with the change of electricity price from $£ 0.06 / \mathrm{kWh}$ to $£ 0.22 / \mathrm{kWh}$ as shown in Fig. 15 (a). The NPV varies from $£ 10,000$ to $£ 33,066$ accounting for the largest proportion of $43.0 \%$ when the electricity price increases from $£ 0.08 / \mathrm{kWh}$ to $£ 0.1349 / \mathrm{kWh}$, meanwhile, the smallest proportion of $10.7 \%$ occurs when the electricity price further increases from $£ 0.1349 / \mathrm{kWh}$ to $£ 0.22 / \mathrm{kWh}$. Likewise, the energy output range of 13,000 kWh to $24,000 \mathrm{kWh}$ affects the savings, cash flows and NPV as presented in Fig.14 (b): the higher energy generation, the greater system performance and larger energy savings, as well as the more NPV and cash flow. When energy output varies from 18,699 $\mathrm{kWh}$ to $24,000 \mathrm{kWh}$, the NPV changes from $£ 10,000$ to $£ 33,066$ and takes up the biggest proportion of $34.3 \%$, while the NPV 
432 lies in the range of $£ 10,000$ to $£ 33,066$ making up the smallest ratio of $17.0 \%$ when the energy output is in the range of 13,000

$433 \mathrm{kWh}$ to $18,699 \mathrm{kWh}$
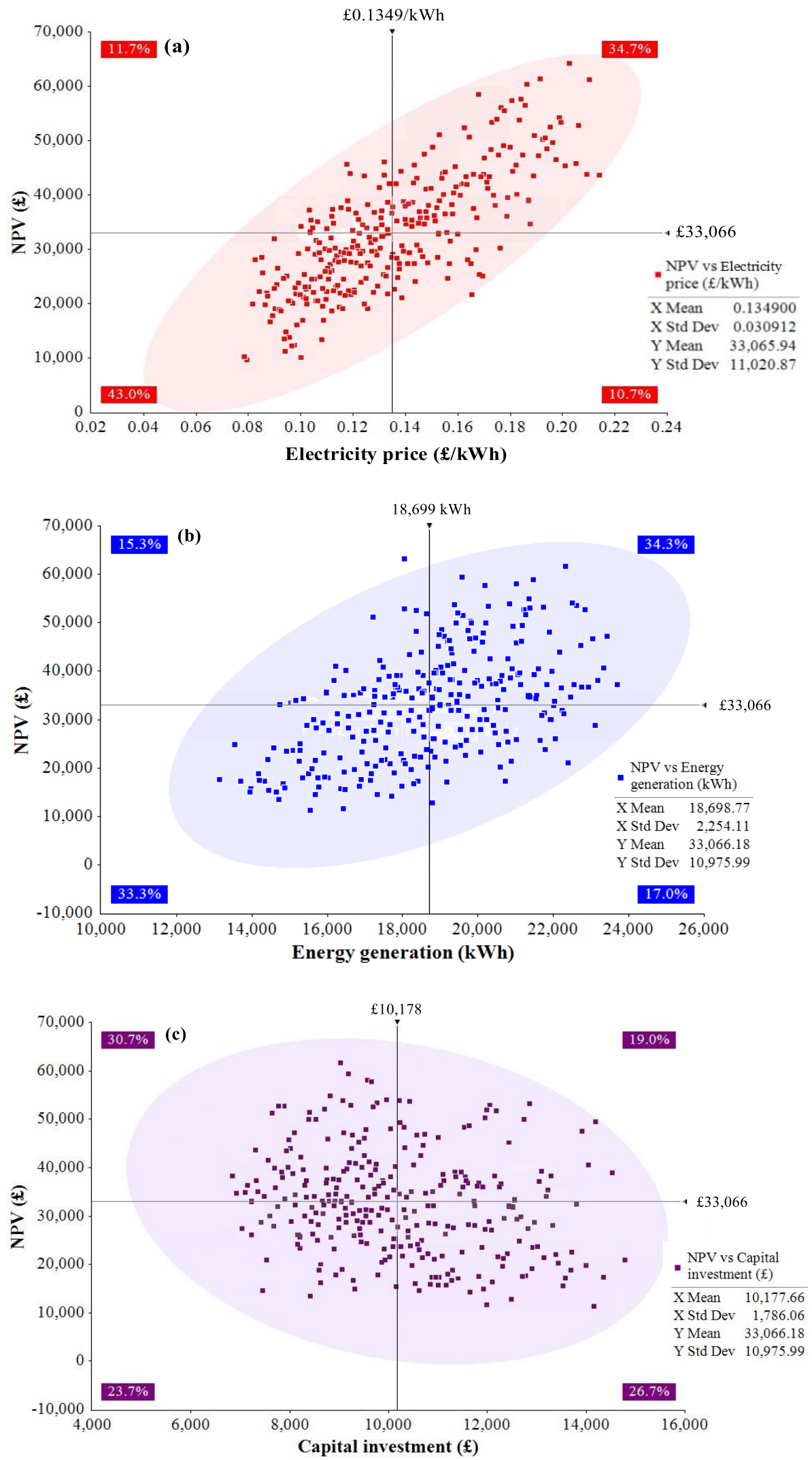


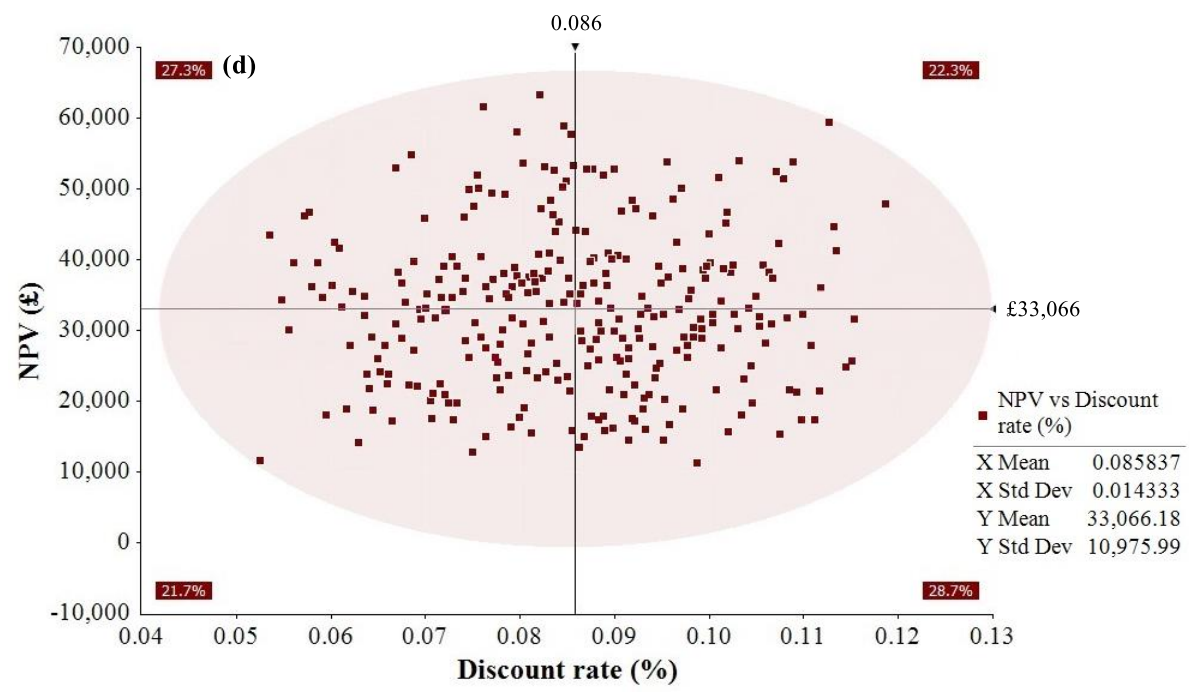

In addition, considering the GCHP system price change in the future, the NPV variation is relative to the capital expense as shown in Fig.15 (c). Compared to the impact of electricity price and energy output, the influence of capital cost is more evenly distributed in the NPV quadrants. For instance, when increasing the GCHP system capital cost from $£ 6,000$ to $£ 10,178$ and from $£ 10,178$ to $£ 15,000$, about $23.7 \%$ and $26.7 \%$ of the NPVs fall below the average value of $£ 33,066$, respectively. This demonstrates that the initial cost of the GCHP system is significant to the final judgement of investment as the higher GCHP price leads to the higher capital cost and loan payment. Therefore, the capital price of the GCHP system should be regulated as even distribution of the NPV value as given in Fig.15 (d). Higher discount rate weakens the present worth of cash flow and energy output, and decreases the NPV. The lower discount rate is beneficial to the investment of the GCHP system.

\subsubsection{Payback period variation with the uncertain input parameters}

The payback period is sensitive to several key parameters, including electricity price ( $£ / \mathrm{kWh})$, capital investment (£) and energy generation $(\mathrm{kWh})$ (see Figs.16-18). Uncertainty associated with electricity price significantly affects the total operating cost (i.e., electricity consumption), energy output and NPV. According to Fig.16, the low electricity price reduces the operating and electricity costs, and increases the payback period up to about 6.18 years relative to the baseline of about 4.31 years. On the other hand, the high electricity price makes the payback period as short as 2.88 years. Likewise, uncertainty in energy output is closely related to the financial credit achieved from reduced electricity consumption. Thus, the range of energy output by using the GCHP system gives rise to a payback period range of approximately 3.51-5.46 years. If lower capital investment can be obtained, the payback period can be achieved about 3.17 years while higher capital investment induces a longer term to achieve positive NPV (up to about 5.70 years). 


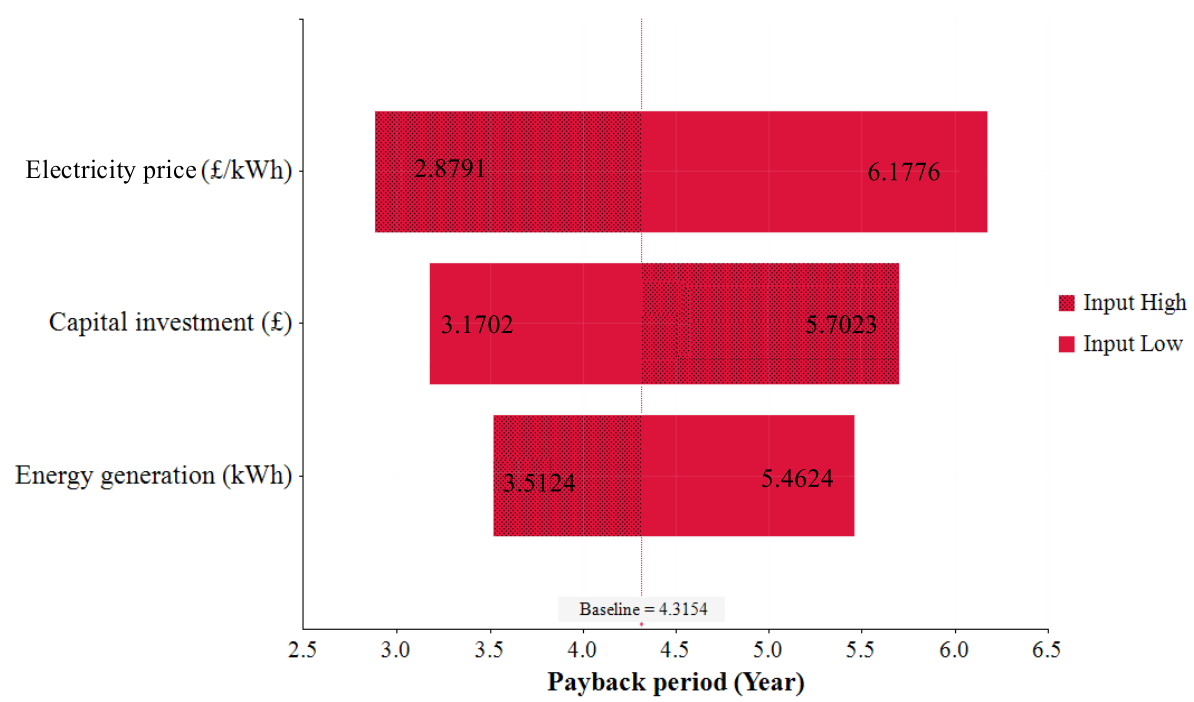

Fig.16. Tornado chart of payback period variation with uncertain input parameters

460 Fig. 17 presents the correlation of payback period. The high electricity price has a good chance $(38.7 \%$ versus $6.7 \%)$ to reduce 461 payback period to below 4.31 years. But for lower electricity price, there is a possibility of $36.0 \%$ that payback period is over 462 the mean value as shown in Fig.17 (a). Scenarios in the lower half of Fig.17 (b) have low payback period (<4.31 years) while 463 those in the left-hand side of the figure have lower capital investment $(<£ 10,178)$. The payback period is therefore located in the 464 lower left quadrant with a possibility of $40.0 \%$. The correlation between the payback period and energy generation presents a 465 pretty even distribution in the four quadrants as shown in Fig. 17 (c). The possibility of reducing the payback period below the 466 mean value (4.31 years) is $57.3 \%$, with $20.3 \%$ for energy generation lower than $18,699 \mathrm{kWh}$ and $37 \%$ for energy generation over $467 \quad 18,699 \mathrm{kWh}$.

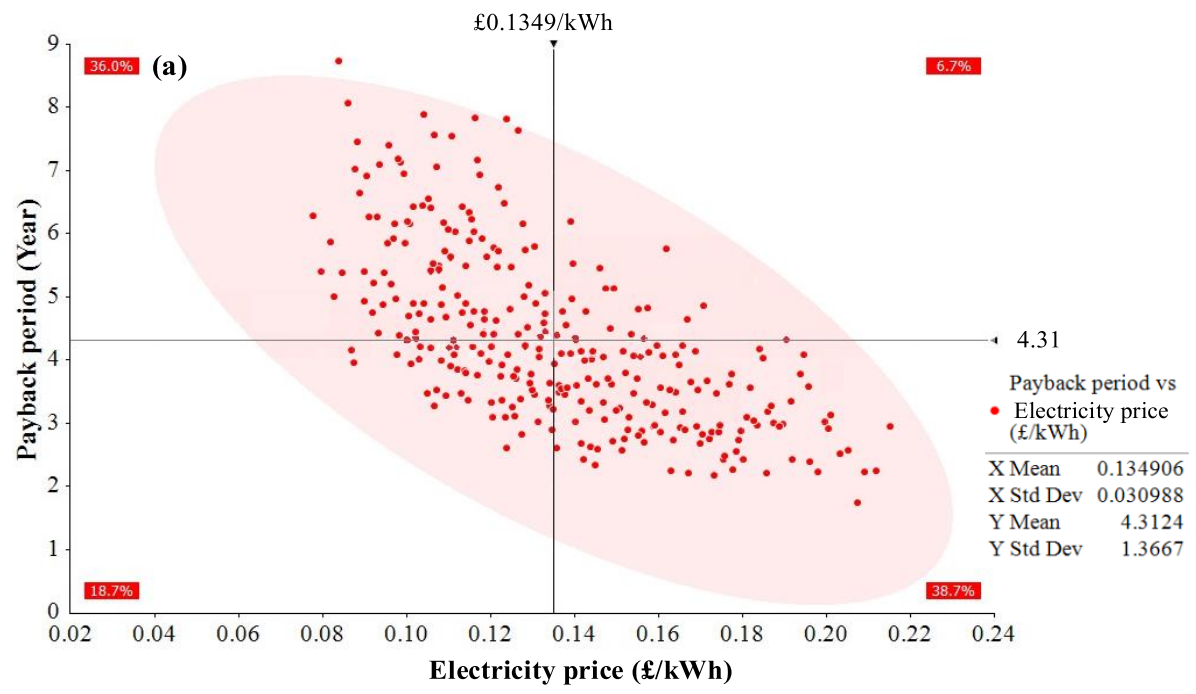



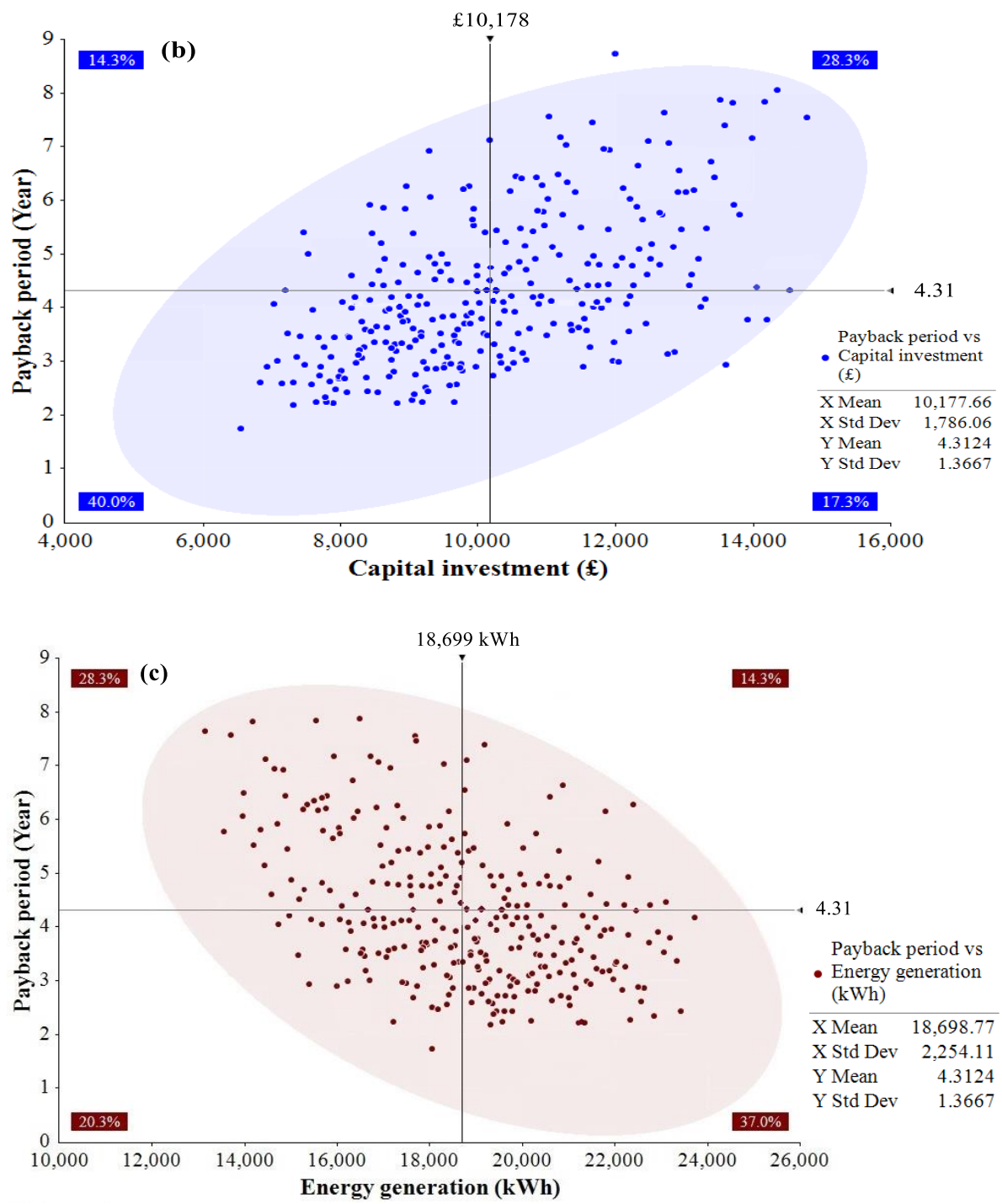

Fig.17. Payback period against variations of: (a) electricity price; (b) capital cost; (c) energy generation

473 4.3.3 Payback period variation with NPV

474 It can be seen from Fig. 18 that $38.0 \%$ of probability NPV value is lower than the average value of $£ 33,066$ when the payback 475 period is above the mean value (4.31-8.50 years). Only $4.7 \%$ of chance NPV is higher than the average value, indicating the long 476 payback time is detrimental to the total NPV. If payback period can be achieved less than 4.31 years, there is a possibility of $47745.0 \%$ that the NPV value is higher than the mean value whereas a chance of $12.3 \%$ for lower value. This indicates that the high 478 NPV value (the upper left side of the figure) can be achieved when the payback period is shortened in the case. 


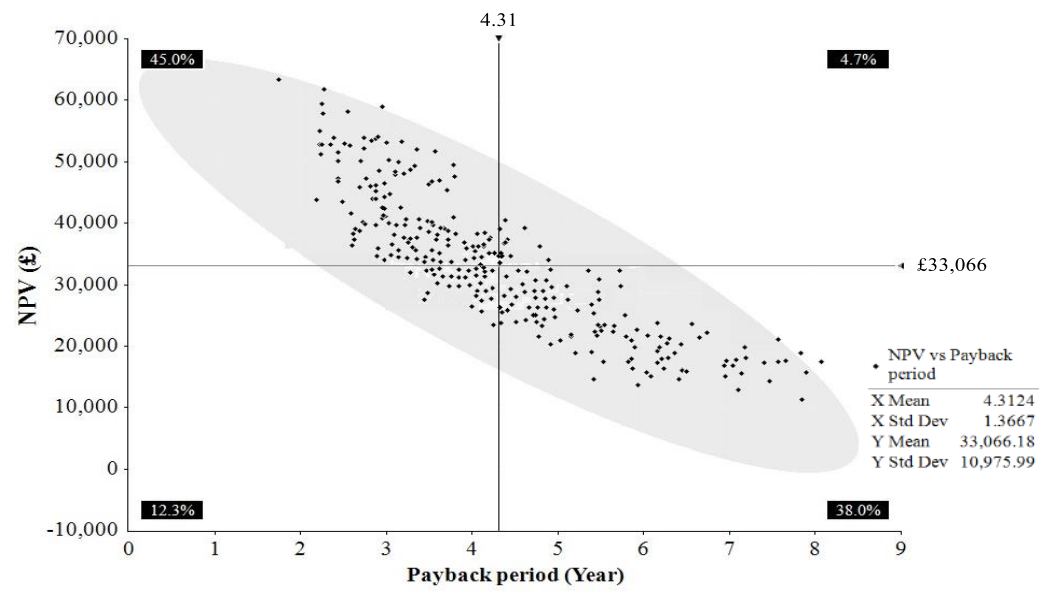

\section{$481 \quad$ 5. Conclusions}

A techno-economic assessment on a GCHP system with multiple EPs for a domestic building in Birmingham, UK is presented in this paper. 16 EPs are utilized as the ground heat exchangers, and a $5.9 \mathrm{~kW}$ nominal heat pump is connected to the EPs. A $2 \mathrm{D}$

Fig.18. Payback period variation with NPV thermal resistance model of the GCHP system is employed to determine its monthly energy output (heating and cooling), ground energy extracted/rejected, electrical energy consumption and system performance (COP and EER) through the EES software. Furthermore, the financial benefit of the GCHP system is evaluated by using the @ Risk software, a complete LCC method with consideration for the time value of money is adopted and some key parameter effects on the LCC are assessed, such as interest rate, income tax rate, LP, SEC, CI, MC, EPT, EPS, ITS, NPV and cumulative EPS. The critical conclusions are obtained as follows:

(1) The energy output (heating and cooling) of the GCHP system could meet the space heating and cooling demands of the domestic building with the annual average COP of 3.63 and EER of 4.62 .

(2) The NPV of the GCHP system is $£ 26,095.41$ at the market discount rate of $8.75 \%$ for a 20 -year operating period.

(3) The cumulative EPS becomes positive by the end of the first year, afterwards it keeps positive until the life cycle is completed.

(4) The cumulative SEC saving $(£ 9,166)$ exceeds the initial cost $(£ 9,033)$ by the end of the fourth year, the cumulative EPS $(£ 9,531.53)$ surpasses the remaining principal balance $(£ 7,106.28)$ by the end of the fifth year. The system payback period is 4.31 years.

(5) The high discount rate reduces the GCHP system energy output and NPV; the low discount rate contributes to the system capital cost.

(6) The payback period is sensitive to electricity price, capital investment and energy output. The high capital investment induces a long term to achieve positive NPV.

For the future research work, a more detailed LCC in comparison with other conventional systems will be investigated. 


\section{References}

503 [1] Directive 2010/31/EU of the European parliament and of the Council of 19 May 2010 on the energy performance of buildings. 504 Official Journal of the European Union; 2010.

[2] Fadejev J, Simson R, Kurnitski J, Haghighat F. A review on energy piles design, sizing and modelling. Energy 2017;122: 390-407.

3] Habibi M, Hakkaki-Fard A. Evaluation and improvement of the thermal performance of different types of horizontal ground heat exchangers based on techno-economic analysis. Energy Conversion and Management 2018; 171:1177-1192.

[4] Zarrella A, Emmi G, Carli MD. A simulation-based analysis of variable flow pumping in ground source heat pump systems with different types of borehole heat exchangers: A case study. Energy Conversion and Management 2017; 131:135-150.

[5] Emmi G, Zarrella A, Carli MD, Galgaro A. An analysis of solar assisted ground source heat pumps in cold climates. Energy Conversion and Management 2015; 106: 660-675.

[6] Cui Y, Zhu J, Twaha S, Riffat SB. A comprehensive review on 2D and 3D models of vertical ground heat exchangers. Renewable and Sustainable Energy Reviews 2018; 94: 84-114.

[7] You T, Wang B, Wu W, Shi W, Li X. Performance analysis of hybrid ground-coupled heat pump system with multi-functions. Energy Conversion and Management 2015; 92: 47-59.

[8] Rammal D, Mroueh H, Burlon S. Impact of thermal solicitations on the design of energy piles. Renewable and Sustainable Energy Reviews 2018; 92: 111-120.

[9] Zhang W, Cui P, Liu J, Liu X. Study on heat transfer experiments and mathematical models of the energy pile of building. Energy and Buildings 2017; 152: 643-652.

[10] Gultekin A, Aydin M, Sisman A. Thermal performance analysis of multiple borehole heat exchangers. Energy Conversion and Management 2016; 122: 544-551.

[11] Yoon S, Lee SR, Xue J, Zosseder K, Go G H, Park H. Evaluation of the thermal efficiency and a cost analysis of different types of ground heat exchangers in energy piles. Energy Conversion and Management 2015; 105: 393-402.

[12] Saeidi R, Noorollahi Y, Esfahanian V. Numerical simulation of a novel spiral type ground heat exchanger for enhancing heat transfer performance of geothermal heat pump. Energy Conversion and Management 2018; 168: 296-307.

[13] Fadejev J, Simson R, Kurnitski J, Haghighat F. A review on energy piles design, sizing and modelling. Energy 2017; 122: 390-407.

[14] Laloui L, Donna A. Understanding the behaviour of energy geo-structures. Proceedings of ICE, Civil Engineering 2011; 164: $184-191$. 
[15] Pahud D, Hubbach M. Measured thermal performances of the energy pile system of the dock midfield at Zürich airport. Available at: <https://pangea.stanford.edu/ERE/pdf/IGAstandard/EGC/2007/195.pdf > 2007 [Assess 06.2007].

[16] Fisch MN, Himmler R. International solar centre Berlin - a comprehensive energy design. In: Fifth international conference for enhanced building operations. Pittsburgh, Pennsylvania, USA, 2005.

535 [17] Brandl H. Thermo-active ground-source structures for heating and cooling. Procedia Engineering 2013; 57: 9-18.

[18] Suckling TP, Smith PEH. Environmentally friendly geothermal piles at Keble College, Oxford, UK. International conference on piling and deep foundations 2002; 445-452.

[19] Laloui L, Donna AD. Energy geostructures: innovation in underground engineering. Wiley-Blackwell 2013.

539 [20] Ozudogrua TY, Olgunb CG, Senola A. 3D numerical modelling of vertical geothermal heat exchangers. Geothermics 2014; 51: $312-324$.

[21] Hamada Y, Saitoh H, Nakamura M, Kubota H, Ochifuji K. Field performance of an energy pile system for space heating. Energy and Buildings 2007; 39: 517-524.

[22] Darkwa J, Su W, Chow DHC. Heat dissipation effect on a borehole heat exchanger coupled with a heat pump. Applied Thermal Engineering 2013; 60: 234-241.

[23] Kim J, Jang JC, Kang EC, Chang KC, Lee EJ, Kim Y. Verification study of a GSHP system manufacturer data based modelling. Renewable Energy 2013; 54:55-62.

[24] Capozza A, Zarrella A, Carli MD. Long-term analysis of two GSHP systems using validated numerical models and proposals to optimize the operating parameters. Energy and Buildings 2015; 93: 50-64.

[25] Bristow D, Kennedy CA. Potential of building-scale alternative energy to alleviate risk from the future price of energy. Energy Policy 2010; 38 (4): 1885-1894.

[26] Yoon S, Lee SR. Life cycle cost analysis and smart operation mode of ground source heat pump system. Smart Structures and System 2015; 16 (4): 743-758.

[27] Chiasson AD. Life-cycle cost study of a geothermal heat pump system bia office building, Winnebago, NE. Midwest Research Institute (Geo-Heat Center, Oregon Institute of Technology), 2006.

[28] Morrone B, Coppola G, Raucci V. Energy and economic savings using geothermal heat pumps in different climates. Energy Conversion and Management 2014; 88: 189-198.

[29] Vu NB, Lee SR, Park S, Yoon S, Go GH, Kang HB. Life cycle cost analysis for ground-coupled heat pump systems including several types of heat exchangers. International Journal of Architecture, Engineering and Construction 2013; 2: 17-24.

[30] Ren C, Deng Y, Cao SJ. Evaluation of polyethylene and steel heat exchangers of ground source heat pump systems based on seasonal performance comparison and life cycle assessment. Energy and Buildings 2018: 162: 54-64. 
561 [31] Canbek C. Life-cycle cost study of ground source heat pumps in hot humid climate zone. Florida International University. Available at: < http://digitalcommons.fiu.edu/cgi/viewcontent.cgi?article=3200\&context=etd $>2010$ [Accessed 10.2010].

[32] Zhu Y, Tao Y, Rayegan R. A comparison of deterministic and probabilistic life cycle cost analyses of ground source heat pump (GSHP) applications in hot and humid climate. Energy and Buildings 2012; 55: 312-321.

[33] Lu Q, Narsilio GA, Aditya GR, Johnston IW. Economic analysis of vertical ground source heat pump systems in Melbourne. Energy 2017; 125:107-117.

[34] Arat H, Arslan O. Exergoeconomic analysis of district heating system boosted by the geothermal heat pump. Energy 2017; 109:1159-1170.

[35] Saner D, Juraske R, Kubert M, Blum P, Hellweg S, Bayer P. Is it only $\mathrm{CO}_{2}$ that matters? A life cycle perspective on shallow geothermal systems. Renewable \& Sustainable Energy Review 2010; 14 (7): 1798-1813.

[36] Huang B, Mauerhofer V. Life cycle sustainability assessment of ground source heat pump in Shanghai, China. Journal of Cleaner Production 2016; 119: 207-214.

[37] Hong T, Kim J, Chae M, Park J, Jeong J, Lee M. Sensitivity analysis on the impact factors of the GSHP system considering energy generation and environmental impact using LCA. Sustainability 2016; 8 (4): 376-388.

[38] Gabrielli L, Bottarelli M. Financial and economic analysis for ground-coupled heat pumps using shallow ground heat exchangers. Sustainable Cities and Society 2016; 20: 71-80.

[39] Wood CJ. Investigation of novel ground source heat pump, in: Built Environment, Vol. Doctor of Philosophy, University of Nottingham, 2009.

[40] Wood CJ, Liu H, Riffat SB. An investigation of the heat pump performance and ground temperature of a piled foundation heat exchanger system for a residential building. Energy 2010; 35: 4932-4940.

[41] Greenline HT Plus. Available at: <http://www.intelligentenergysolutions.com/assets/images/Datasheets/Ground Source Heat Pumps/IE SIVT Green line HTPlus.pdf > 2008 [Accessed 09.2008].

[42] Girard A, Gago EJ, Muneer T, Caceres G. Higher ground source heat pump COP in a residential building through the use of solar thermal collectors. Renewable Energy 2015; 80: 26-39.

[43] Arat H, Arslan O. Exergoeconomic analysis of district heating system boosted by the geothermal heat pump. Energy 2017; 109:1159-1170.

[44] Sharqawy M, Mokheimer EM, Badr HM. Effective pipe-to-borehole thermal resistance for vertical ground heat exchangers. Geothermics 2009; 38: 271-277.

[45] Loveridge F, Powrie W. 2D thermal resistance of pile heat exchangers. Geothermics 2014; 50: 122-135. 
590 [46] Cui Y, Zhu J. Year-round performance assessment of a ground source heat pump with multiple energy piles. Energy and Buildings 2018; 158: 509-524.

592 [47] Zanchini E, Jahanbin A. Effects of the temperature distribution on the thermal resistance of double u-tube borehole heat exchangers. Geothermics 2018; 71: 46-54.

594 [48] Kambanou ML, Lindahl M. A literature review of life cycle costing in the product-service system context. Procedia CIRP 2016; 47:186-191.

596 [49] Chong WT, Naghavi MS, Poh SC, Mahlia TMI, Pan KC. Techno-economic analysis of a wind-solar hybrid renewable energy system with rainwater collection feature for urban high-rise application. Applied Energy 2011; 88: 4067-4077.

598 [50] Buker MS, Mempouo B, Riffat SB. Performance evaluation and techno-economic analysis of a novel building integrated PV/T roof collector: An experimental validation. Energy and Buildings 2014; 76: 164-175.

600 [51] Energy price - Parliament UK. House of Commons Library. Available at: <https://researchbriefings.parliament.uk/Resear

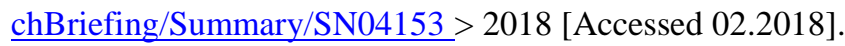

602 [52] Ofgem. Domestic renewable heat incentive. <https://www.ofgem.gov.uk/environmental-programmes/domest ic-rhi>.

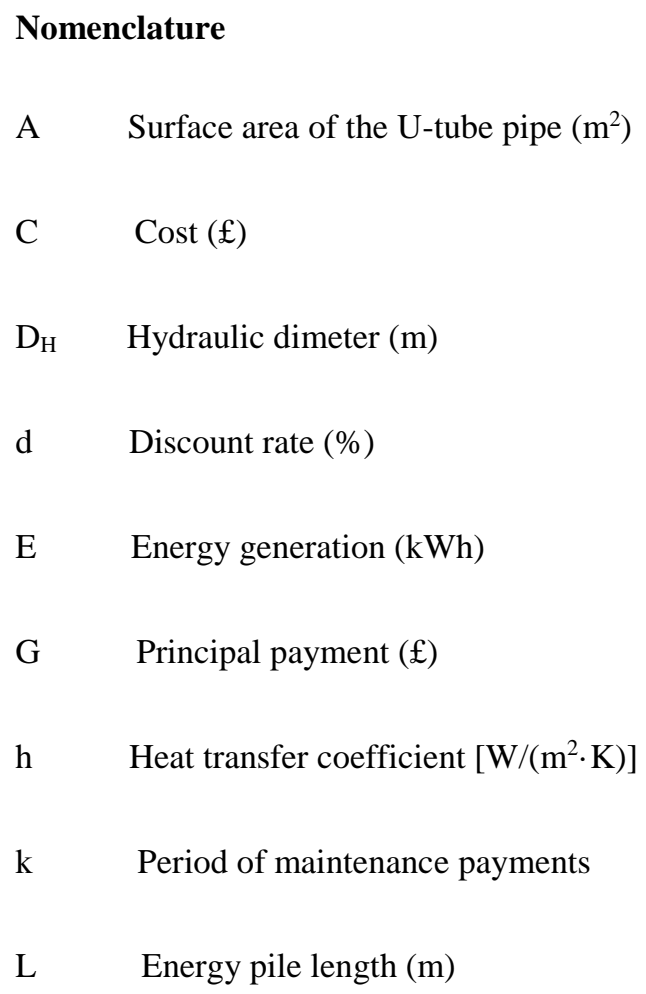




\begin{tabular}{|c|c|}
\hline $\mathrm{N}$ & Period of economic assessment \\
\hline $\mathrm{Nu}$ & Nusselt number \\
\hline $\mathrm{n}$ & Polytropic compression coefficient \\
\hline $\mathrm{P}$ & Pressure $(\mathrm{kPa})$ \\
\hline $\operatorname{Pr}$ & Prandtl number \\
\hline $\mathrm{R}$ & Thermal resistance $(\mathrm{K} / \mathrm{W})$ \\
\hline $\operatorname{Re}$ & Reynolds number \\
\hline $\mathrm{r}$ & Radius (m) \\
\hline s & Year number of periodic payments \\
\hline $\mathrm{T}$ & Temperature $\left({ }^{\circ} \mathrm{C}\right)$ \\
\hline $\mathrm{t}$ & Time (s) \\
\hline $\mathrm{U}$ & Overall heat transfer coefficient $\left(\mathrm{W} / \mathrm{m}^{2} \cdot \mathrm{K}\right)$ \\
\hline W & Rate of work input (kW) \\
\hline $\mathrm{z}$ & Number of loan payment years \\
\hline \multicolumn{2}{|c|}{ Subscripts } \\
\hline $\mathrm{c}$ & Cooling output from heat pump \\
\hline comp & Compressor \\
\hline fluid & Fluid \\
\hline $\mathrm{h}$ & Heat output from heat pump \\
\hline inlet & Inlet fluid temperature \\
\hline outlet & Outlet fluid temperature \\
\hline pipe & Pipe \\
\hline pump & Pump \\
\hline
\end{tabular}




\begin{tabular}{|c|c|}
\hline soil & Soil \\
\hline total & Total \\
\hline \multicolumn{2}{|c|}{ Greek Letters } \\
\hline$\alpha$ & Period of extra property tax $(\%)$ \\
\hline$\beta$ & UK electricity rate $(£ / \mathrm{kWh})$ \\
\hline$\gamma$ & Inflation rate of extra property tax $(\%)$ \\
\hline$\zeta$ & Number of pipes in the EP \\
\hline$\lambda$ & Thermal conductivity $\left(\mathrm{W} / \mathrm{m}^{2} \cdot \mathrm{K}\right)$ \\
\hline$\rho$ & Density $\left(\mathrm{kg} / \mathrm{m}^{3}\right)$ \\
\hline$v$ & Working fluid velocity $\left(\mathrm{m}^{2} / \mathrm{s}\right)$ \\
\hline$\mu$ & Working fluid dynamic viscosity $(\mathrm{Pa} \cdot \mathrm{s})$ \\
\hline \multicolumn{2}{|c|}{ Abbreviations } \\
\hline ASHP & Air source heat pump \\
\hline $\mathrm{CI}$ & Capital investment \\
\hline $\mathrm{COP}$ & Coefficient of performance \\
\hline $\mathrm{DC}$ & Direct expansion \\
\hline DCFA & Discounted cash flow analysis \\
\hline DPB & Discounted payback time \\
\hline EER & Energy efficiency ratio \\
\hline EES & Engineering equation solver \\
\hline EP & Energy pile \\
\hline EPS & Energy pile system savings \\
\hline EPT & Extra property tax \\
\hline
\end{tabular}




\begin{tabular}{|c|c|}
\hline ETR & Effective tax rate \\
\hline GHE & Ground heat exchanger \\
\hline GCHP & Ground-coupled heat pump \\
\hline ITS & Income tax savings \\
\hline LCA & Life-cycle assessment \\
\hline LCC & Life-cycle cost \\
\hline LMTD & Logarithmic mean temperature difference \\
\hline LP & Loan payment \\
\hline $\mathrm{MC}$ & Maintenance cost \\
\hline NPV & Net present value \\
\hline PC & Periodic cost \\
\hline RHI & Renewable heat incentive \\
\hline SEC & System energy cost \\
\hline SPB & Simple payback period \\
\hline
\end{tabular}

